Linköping University Medical Dissertation

No. 1574

\title{
Molecular Mechanisms of Resin Acids and Their Derivatives on the Opening of a Potassium Channel
}

\author{
Nina Ottosson
}

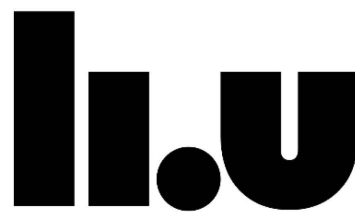

LINKÖPING UNIVERSITY

Department of Clinical and Experimental Medicine Linköping University, Sweden

Linköping 2017 
(c) Nina Ottosson, 2017

Cover picture shows Wu122 [white], a resin-acid derivative, bound to a voltage-sensor domain of the voltage-gated Shaker $\mathrm{K}_{\mathrm{v}}$ channel (yellow) inserted in the membrane [grey]. Picture was done by Samira Yazdi.

Printed in Sweden by LiU-Tryck, Linköping, Sweden, 2017

ISBN: 978-91-7685-521-8

ISNN: 0345-0082 
To Erik, Oskar, and Tilde 



\section{Table of contents}

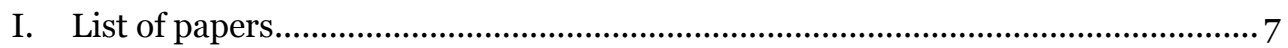

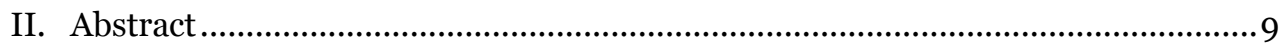

III. Populärvetenskaplig sammanfattning ..........................................................11

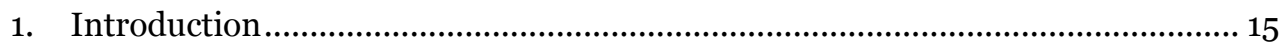

1.1 Voltage-gated ion channels in physiology .............................................. 15

1.2 Voltage-gated ion channels as drug targets.......................................... 16

1.3 The molecular structure of voltage-gated ion channels .......................... 17

1.3.1 The molecular structure of the Shaker $\mathrm{K}_{\mathrm{v}}$ channel ................................ 17

1.4 The voltage sensor and voltage sensing in the Shaker $K_{v}$ channel ............ 18

1.4.1 The gating charges in the voltage sensor makes the channel voltage

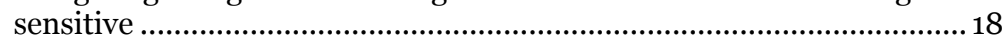

1.4.2 Upward movement of the voltage sensors activates the channel ........... 19

1.4.3 The last movement of the voltage sensor opens the pore.......................19

1.4.4 The open channel can inactivate by two mechanisms............................20

1.4.5 Downward movement of the voltage sensors closes the channel............20

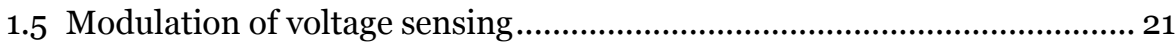

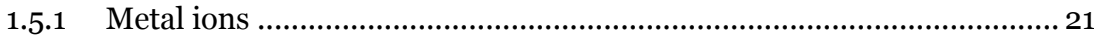

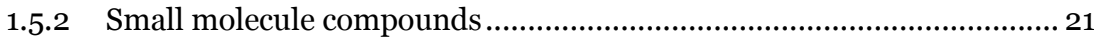

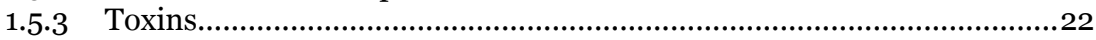

1.5.4 Polyunsaturated fatty acids .................................................................23

1.6 The lipoelectric mechanism ..................................................................24

1.6.1 The ketogenic diet and polyunsaturated fatty acids ...............................24

1.6.2 PUFAs modify a $\mathrm{K}_{\mathrm{v}}$ channel by the lipoelectric mechanism...................24

1.6.3 The lipoelectric mechanism as a new pharmacological mechanism ......25

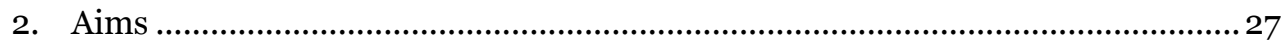

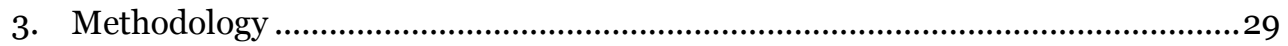

3.1 Mutagenesis .......................................................................................29

3.2 Preparation of oocytes and expression of ion channels ..........................29

3.3 Electrophysiological recordings ..........................................................30

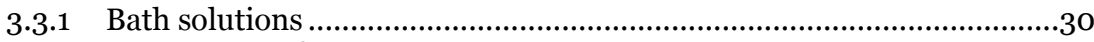

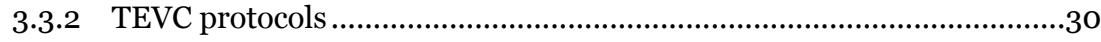

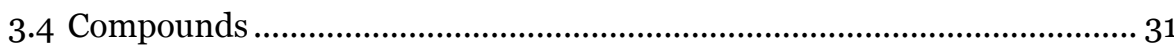

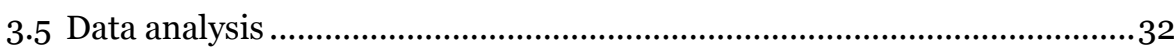

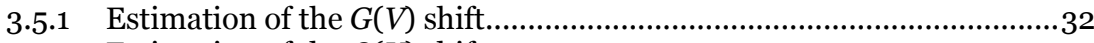

3.5.2 Estimation of the $Q(V)$ shift..................................................................33

3.5.3 Estimation of time constants ..................................................................3

3.5.4 Chemical properties of the compounds .................................................... 33

3.5.5 Molecular docking and dynamics ........................................................ 34

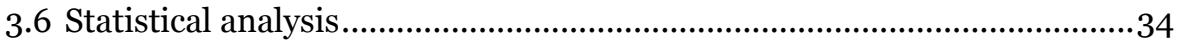


4. Results and discussion

4.1 Aim 1: To explore the importance of charges in the top of $\mathrm{S} 4$ and to construct a channel supersensitive to PUFAs ....

4.1.1 Modifications of the charge pattern altered the PUFA-induced $G(V)$ shift

4.1.2 Combinations of charged residues potentiated the DHA-induced $G(V)$ shift

4.2 Aim 2: To identify and improve small-molecule compounds that act by the lipoelectric mechanism

4.2.1 Pimaric acid is a Shaker $\mathrm{K}_{\mathrm{v}}$ channel opener ........................................39

4.2.2 Podocarpic acid did not open the Shaker $\mathrm{K}_{\mathrm{v}}$ channel due to a hydroxyl group

4.2.3 Dehydroabietic acid was selected as our main scaffold for derivatives.

4.2.4 Side chains at the B-ring affected chemical and ion-channel opening properties

4.2.5 Halogenation of the C-ring affected chemical- and ion channel opening properties

4.2.6 Side chains at the B-ring in combination with halogenation of the C-ring potentiated the opening effect

4.2.7 Halogens can be replaced with specific hydrocarbons with preserved efficacy

4.3 Aim 3: To map the Shaker $\mathrm{K}_{\mathrm{v}}$ channel binding site for small-molecule compounds from aim 2

4.3.1 Resin acids and their derivatives needed to be negatively charged to act as openers

4.3.2 Resin acids and their derivatives acted on the opening step.................45

4.3.3 The most efficient openers also slowed down channel closure ................45

4.3.4 A cysteine-scan identified the $\mathrm{S}_{3}$ helix as important for the interaction.

4.3.5 Molecular docking and molecular dynamics identified a binding

4.3.6 Modifications of the charge pattern supported the suggested

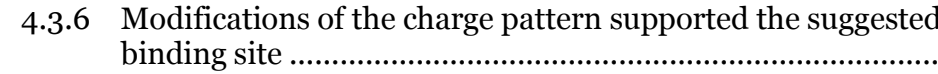

4.4 Aim 4: To evaluate the pharmacological potency of the smallmolecule compounds from aim 2 to reduce neuronal electrical excitability

5. Concluding remarks.

5.1 Functional similarities and differences between PUFAs and resin acids

5.2 Resin-acid effects on other potassium channels . .50

6. Acknowledgements 51

7. References 


\section{List of papers}

This thesis is based on the following papers, referred to by their Roman numerals:

I. Ottosson, N.E., Liin, S.I., and Elinder, F. (2014) Drug-induced ion channel opening tuned by the voltage sensor charge profile. Journal of General Physiology 143(2):173-182.

II. Ottosson, N. E., Wu, X., Nolting, A., Karlsson, U., Lund, P.-E., Ruda, K., Svensson, S., Konradsson P., and Elinder, F. (2015). Resin-acid derivatives as potent electrostatic openers of voltage-gated $\mathrm{K}$ channels and suppressors of neuronal excitability. Scientific Reports 5:13278.

III. Ottosson, N. E., Silverå-Ejneby, M., Wu, X., Yazdi, S., Konradsson P., Lindahl, E., and Elinder, F. (2017) A drug pocket at the lipid bilayerpotassium channel interface. Manuscript 


\section{Abstract}

Voltage-gated ion channels play fundamental roles in excitable cells, such as neurons, where they enable electric signaling. Normally, this signaling is well controlled, but brain damage, alterations in the ionic composition of the extracellular solution, or dysfunctional ion channels can increase the electrical excitability thereby causing epilepsy. Voltage-gated ion channels are obvious targets for antiepileptic drugs, and, as a rule of thumb, excitability is dampened either by closing voltagegated sodium channels ( $\mathrm{Na}_{\mathrm{v}}$ channels) or by opening voltage-gated potassium channels ( $\mathrm{K}_{\mathrm{v}}$ channels). For example, several classical antiepileptic drugs block the ion-conducting pore of $\mathrm{Na}_{\mathrm{v}}$ channels. Despite the large number of existing antiepileptic drugs, one third of the patients with epilepsy suffer from intractable or pharmacoresistant seizures.

Our research group has earlier described how different polyunsaturated fatty acids (PUFAs) open a $\mathrm{K}_{\mathrm{v}}$ channel by binding close to the voltage sensor and, from this position, electrostatically facilitate the movement of the voltage-sensor, thereby opening the channel. However, PUFAs affect a wide range of ion channels, making it difficult to use them as pharmaceutical drugs; it would be desirable to find smallmolecule compounds with an electrostatic, PUFA-like mechanism of action. The aim of the research leading to this thesis was to find, characterize, and refine drug candidates capable of electrostatically opening a $\mathrm{K}_{\mathrm{v}}$ channel.

The majority of the experiments were performed on the cloned Shaker $\mathrm{K}_{\mathrm{v}}$ channel, expressed in oocytes from the frog Xenopus laevis, and the channel activity was explored with the two-electrode voltage-clamp technique. By systematically mutating the extracellular end of the channel's voltage sensor, we constructed a highly PUFAsensitive channel, called the $3 \mathrm{R}$ channel. Such a channel is a useful tool in the search for electrostatic $\mathrm{K}_{\mathrm{v}}$-channel openers. We found that resin acids, naturally occurring in tree resins, act as electrostatic Shaker $\mathrm{K}_{\mathrm{v}}$ channel openers. To explore the structure-activity relationship in detail, we synthesized 120 derivatives, whereof several were potent Shaker $\mathrm{K}_{\mathrm{v}}$ channel openers. We mapped a common resin acidbinding site to a pocket formed by the voltage sensor, the channel's third transmembrane segment, and the lipid membrane, a principally new binding site for small-molecule compounds. Further experiments showed that there are specific interactions between the compounds and the channel, suggesting promises for further drug development. Several of the most potent Shaker $\mathrm{K}_{\mathrm{v}}$ channel openers also dampened the excitability in dorsal-root-ganglion neurons from mice, elucidating the pharmacological potency of these compounds. In conclusion, we have found that resin-acid derivatives are robust $\mathrm{K}_{\mathrm{v}}$-channel openers and potential drug candidates against diseases caused by hyperexcitability, such as epilepsy. 


\section{Populärvetenskaplig sammanfattning}

Vi drivs av elektricitet och varje tanke, varje hjärtslag och varje kroppsrörelse styrs av blixtsnabba elektriska impulser. Impulserna beror på att jonkanaler i cellernas membran öppnar sig och släpper igenom elektriskt laddade joner.

I normala fall är den här elektriska signaleringen väldigt kontrollerad men exempelvis skador i hjärnan kan medföra att den elektriska retbarheten ökar, vilket innebär att de elektriska impulserna skickas för lätt. Om det sker på ett synkroniserat sätt i alltför många nervceller kan ett epileptiskt anfall utlösas. Jonkanalerna är självklara mål för läkemedel som har till uppgift att minska den elektriska retbarheten, exempelvis vid epilepsi. Rent generellt så kan retbarheten antingen minskas genom att spänningsreglerade natriumkanaler (Nav-kanaler) stängs eller att spänningsreglerade kaliumkanaler ( $\mathrm{K}_{\mathrm{v}}$-kanaler) öppnas och den klassiska mekanismen för dagens läkemedel är att stänga Nav-kanaler. Trots att det finns ett stort antal läkemedel mot epilepsi så blir omkring $30 \%$ av patienterna med epilepsi inte anfallsfria av dagens läkemedel. Dessutom orsakar de inte sällan biverkningar såsom yrsel och trötthet. Målet med min forskning var att hitta och karaktärisera nya läkemedelskandidater som reglerar retbarheten genom att öppna $\mathrm{K}_{\mathrm{v}}$-kanaler via en ny farmakologisk mekanism. Innan jag beskriver hur det går till skall jag förklara hur de spänningskänsliga jonkanalerna får en elektrisk signal, en aktionspotential, att fortplantas längs en nervcell.

Normalt är insidan av en nervcell negativt laddad jämfört med utsidan. Vanligtvis är membranpotentialen omkring $-70 \mathrm{mV}$ när cellen är i vila. Koncentrationen av natriumjoner är högre på utsidan än på insidan av cellen och för kaliumjoner gäller det motsatta. För att öppna både $\mathrm{Na}_{v}-$ och $\mathrm{K}_{\mathrm{v}}$-kanalerna krävs det att membranpotentialen blir något mindre negativ än vilopotentialen, exempelvis genom inflöde av natriumjoner genom en närliggande kanal. Då tröskelvärdet för en aktionspotential uppnås, öppnas Nav-kanaler och natriumjoner strömmar in i cellen och förändrar membranpotentialen i positiv riktning. Med lite fördröjning öppnas även $\mathrm{K}_{\mathrm{v}}$-kanaler och kaliumjoner som strömmar ut ur cellen och återställer membranpotentialen vilket avslutar aktionspotentialen. De natriumjoner som passerade in sprider sig längs insidan av membranet och aktiverar närliggande $\mathrm{Na}_{v}$ kanaler vilket leder till en ny aktionspotential och på detta sätt sprider sig aktionspotentialen längs nervcellen. När signalen har nått nervcellens slut orsakar aktionspotentialen en frisättning av signalsubstanser som kemiskt aktiverar nästa nervcell där signalen återigen fortleds tack vare de spänningsreglerade jonkanalerna. Dessa jonkanaler är fascinerande proteiner med en mycket viktig funktion. 
Som ett alternativ till att blockera Nav-kanalerna, vilket för en stor del av epilepsipatienterna inte fungerar och dessutom orsakar allvarliga biverkningar, vill vi finjustera $\mathrm{K}_{\mathrm{v}}$-kanalernas spänningsberoende dvs. hur lätt de öppnar och hur länge de är öppna.

Vår forskargrupp har tidigare kartlagt hur olika fleromättade fettsyror öppnar $\mathrm{K}_{\mathrm{v}^{-}}$ kanaler via denna mekanism och då vi vet att substansen dels måste ha en fettlöslig (lipofil) del och dels ha en negativ laddning har vi kallat den för den lipoelektriska mekanismen. Att utveckla fleromättade fettsyror till läkemedel mot exempelvis epilepsi skulle vara svårt då fleromättade fettsyror påverkar ett stort antal olika jonkanaler via flera bindningsställen. Vi ville hitta småmolekyler som öppnar $\mathrm{K}_{v^{-}}$ kanaler på samma sätt som fleromättade fettsyror men med en mer specifik bindning till jonkanalen för att kunna utveckla selektivitet mot särskilda jonkanaler.

Nästan alla experiment som ligger till grund för min avhandling har gjorts på den klonade Shaker $\mathrm{K}_{\mathrm{v}}$-kanalen, som normalt finns i nervsystemet hos Drosophila melanogaster, bananflugor. Om jonkanalen är defekt i bananflugorna så skakar deras ben, framförallt då flugorna är nedsövda, och därav namnet Shaker. Att testa molekyler som man vill utveckla till läkemedel för människa på en kanal som finns i bananfluga kan tyckas märkligt, men faktum är att jonkanalerna är mycket väl konserverade mellan arter och i vårt nervsystem finns det jonkanaler som är mycket lika Shaker $\mathrm{K}_{\mathrm{v}}$-kanalen. Dessutom är Shaker $\mathrm{K}_{\mathrm{v}}$-kanalen studerad på detaljnivå av vår och många andra forskargrupper världen över och därmed har vi kunskap om jonkanalen som har varit väldigt värdefull i min avhandling. Vi injicerar små mängder av klonat mRNA (mallen) för kanalen in i ägg från Xenopus laevis, den afrikanska klogrodan (grodan sövs och äggen tas ut genom en operation). Grodägget kommer att skapa miljontals kopior av jonkanalen som inkorporeras i äggets membran och vi kan mäta och modifiera jonkanalsaktiviteten med den elektrofysiologiska metoden tvåelektrods voltage-clamp.

Mitt första mål var att skapa en Shaker $\mathrm{K}_{\mathrm{v}}$-kanal med ökad känslighet för fleromättade fettsyror då en sådan kanal skulle fungera som ett robust verktyg i vårt sökande efter nya kaliumkanalsöppnare. Genom att införa två mutationer i den del av kanalen som känner av och reagerar på spänning, spänningssensorn, tillverkade vi en mycket fettsyra-känslig kanal som vi kallade för $3 \mathrm{R}$-kanalen (eller superkanalen). Vi fann att naturligt förekommande hartssyror, som återfinns i kåda från barrträd, exempelvis den svenska tallen, öppnar Shaker $\mathrm{K}_{\mathrm{v}}$-kanalen. Utöver fem naturligt förekommande hartssyror syntetiserade vi även 120 hartssyraderivat med små molekylära förändringar.

Molekylerna syntetiserades av kemister vid Linköpings Universitet, och vi fann tydliga kopplingar mellan molekylernas struktur och med vilken effekt de öppnade 
kaliumkanalen. Vi kunde också visa att dessa molekyler öppnar Shaker $\mathrm{K}_{\mathrm{v}}$-kanalen via samma mekanism som fleromättade fettsyror.

Genom att kombinera omfattande mutationsstudier av jonkanalen med vår kunskap om de 125 hartssyrorna kunde vi med hjälp av datorsimuleringar kartlägga var på kanalen som hartssyrorna binder. Vi fann att de binder till en ficka som formas mellan spänningssensorn och cellmembranet, nära bindningsstället för de fleromättade fettsyrorna. För hartssyrorna kunde vi identifiera tydliga kemiska bindningar mellan substansen och jonkanalen vilket är lovande för fortsatt läkemedelsutveckling av dem.

Vi testade även om molekylerna kunde reglera retbarheten i dorsalrotsganglieneuron (isolerade nervceller) från mus och de som var potenta kaliumkanalsöppnare dämpade även retbarheten i nervcellerna. Mycket jobb kvarstår men vi har med arbetet i min avhandling identifierat hartssyrorna som läkemedelskandidater mot sjukdomar som beror av ökad retbarhet, såsom epilepsi. 


\section{Introduction}

Electrically excitable cells are needed for us to function, to be able to think and to make our hearts beat (Hille 2001). The presence of electricity in animals was first described in the second half of the 18th century by Luigi Galvani who observed bioelectricity in dissected frogs (Galvani 1791). Emil du Bois-Reymond reported that the bioelectricity in nerves and muscle fibers generated an electrical action current (later called action potential) (Du Bois-Reymond 1849), later proposed to be evoked by a change in ion permeability of the membrane (Bernstein 1902). The importance of ions for the electric activity of excitable cells was already known (Ringer 1882), and Hodgkin and Katz showed that it was the change in the permeability of the membrane to sodium ions that generated the action potential (Hodgkin and Katz 1949). The classical studies of Hodgkin and Huxley on the squid giant axon identified sodium (Na), potassium (K), and leak currents as main players affecting the action potential (Hodgkin and Huxley 1952a, Hodgkin and Huxley 1952b, Hodgkin and Huxley 1952c, Hodgkin and Huxley 1952d, Hodgkin et al. 1952). In the 1960s and 1970 s the voltage-gated $\mathrm{Na}$ and $\mathrm{K}$ channels that generate these currents were identified as separate units with water-filled pores (Tasaki and Hagiwar 1957, Narahashi et al. 1964, Armstrong and Binstock 1965). Investigations of the voltagesensing mechanisms have progressed rapidly since then, with the cloning of voltagegated sodium $\left(\mathrm{Na}_{\mathrm{v}}\right)$, potassium $\left(\mathrm{K}_{\mathrm{v}}\right)$, and calcium $\left(\mathrm{Ca}_{\mathrm{v}}\right)$ channels in the 1980 s (Noda et al. 1984, Noda et al. 1986, Tanabe et al. 1987, Tempel et al. 1987) and the first Xray crystal structure of a correctly folded $\mathrm{K}_{\mathrm{v}}$ channel in 2005 (Long et al. 2005a, Long et al. 2005b).

This thesis concerns pharmacological regulation of a $\mathrm{K}_{\mathrm{v}}$ channel. I have studied a mechanism of action that tunes the channel's voltage sensitivity, and thereby regulates the activity of $\mathrm{K}_{\mathrm{v}}$ channels. Compounds acting by this mechanism can potentially be developed into drugs that protect against epileptic seizures, cardiac arrhythmia, and pain. My focus has been to find, characterize, and refine smallmolecule compounds that act by this mechanism. Before discussing my experimental work, I will briefly describe voltage-gated ion channels, why they are important, and how their activity can be modified.

\subsection{Voltage-gated ion channels in physiology}

A voltage-gated ion channel (VGIC) is a transmembrane protein activated by changes in the electrical membrane potential. The membrane potential alters the conformation of the ion channel, regulating its opening and closing. VGICs have a crucial role in excitable cells, such as neuronal and muscle cells. 
The VGICs allow a rapid and coordinated depolarization (membrane potential shifts from negative to more positive) in response to membrane potential alterations, enabling a controlled propagation of an electrical signal, the action potential. I will now describe how the action potential propagates through a neuron.

When the threshold for the action potential firing is reached, Nav channels open and cause a rapid influx of $\mathrm{Na}^{+}$, depolarizing the membrane potential. Then, $\mathrm{K}_{\mathrm{v}}$ channels open and the efflux of $\mathrm{K}^{+}$repolarizes the membrane potential back to the resting membrane potential. VGICs are expressed along the neuron, and the depolarization activates adjacent channels. Thus, the action potential propagates via $\mathrm{Na}_{\mathrm{v}}$ and $\mathrm{K}_{\mathrm{v}}$ channels along the axon from the soma to the axon terminal, a region enriched in $\mathrm{Cav}_{\mathrm{v}}$ channels. Upon depolarization, $\mathrm{Ca}_{\mathrm{v}}$ channels open and the influx of calcium will cause a release of neurotransmitters to the synaptic cleft, the narrow space between two neurons. The neurotransmitters bind to dendritic receptors on the post-synaptic neuron and the signal can propagate. In general, this electrical signaling is very well controlled, and an action potential is not fired if the incoming signal is not powerful enough. However, several diseases such as epilepsy are caused by dysfunctional signaling (Ashcroft 2000), further described in the following chapter.

\subsection{Voltage-gated ion channels as drug targets}

A large number of pathophysiological conditions like epilepsy, cardiac arrhythmia, and chronic pain and are caused by disturbed excitability making the ion channels an obvious target for pharmacological drugs (Ashcroft 2000). In fact, ion channel drugs constitute the second largest group among approved drugs and about $13 \%$ of today's drugs target different ion channels (Overington et al. 2006). Unfortunately, many patients do not satisfactorily respond to available drugs. For instance, one third of patients with epilepsy suffer from intractable or pharmacoresistant seizures (Lefevre and Aronson 2000, Sillanpaa and Schmidt 2006, Schuele and Luders 2008, Brodie et al. 2012, Loscher et al. 2013) and many anti-epileptic drugs are associated with serious adverse effects (Sankar and Holmes 2004, Loring et al. 2007).

Consequently, there is a large need for new drugs to reduce symptoms such as epileptic seizures. The general aim throughout my projects has been to investigate if we can find small-molecule compounds acting by the lipoelectric mechanism, a mechanism different from the mechanism used in the drugs of today to reduce electrical excitability. Compounds acting by the lipoelectric mechanism tune the voltage sensitivity of a channel and thereby regulate the activity of the channel. Hopefully, these compounds can be developed into medical drugs against epilepsy, cardiac arrhythmia, and pain. In the last section of this introduction (1.6), I describe the lipoelectric mechanism. 
First I will describe the molecular structure and function of voltage-gated ion channels, and then the molecular principle of some existing toxins and drugs affecting voltage-gated channels.

\subsection{The molecular structure of voltage-gated ion channels}

A VGIC consists of a pore-forming unit surrounded by four voltage-sensor domains (VSDs; (Long et al. 2007)) (Figure 1A). A selectivity filter in the center of the pore determines what ions can pass through the pore (Figure 1A) (Hille 1972). In general, a VGIC consists of four domains or subunits, each having six transmembrane helices (S1-S6) (Figure 1B). The pore is composed of the four S5-S6 helices. The Nav consist of four linked subunits, the four domains (I-IV) (Noda et al. 1984). Each VSD is composed of four transmembrane helices (S1-S4), where S4 contains several regularly spaced positively charged amino acids residues (Figure $1 \mathrm{C}$ ), so-called gating charges (first identified as positively charged gating particles) (Armstrong and Bezanilla 1973, Keynes and Rojas 1974). Cav channels have a similar structure. Contrary to $\mathrm{Nav}_{\mathrm{v}}$ and $\mathrm{Cav}_{\mathrm{v}}$ channels, $\mathrm{K}_{\mathrm{v}}$ channels are composed of tetramers that each resemble one domain of $\mathrm{Na}_{\mathrm{v}}$ or $\mathrm{Cav}$ channels. Other families of ion channels, like the calcium-activated potassium channels, $\mathrm{K}_{\mathrm{Ca}}$ channels, also have this $\mathrm{K}_{\mathrm{v}}$-resembling architecture (Frank et al. 2005). The molecular relationships between different VGICs were reviewed by Catterall and coworkers in 2005 (Frank et al. 2005).
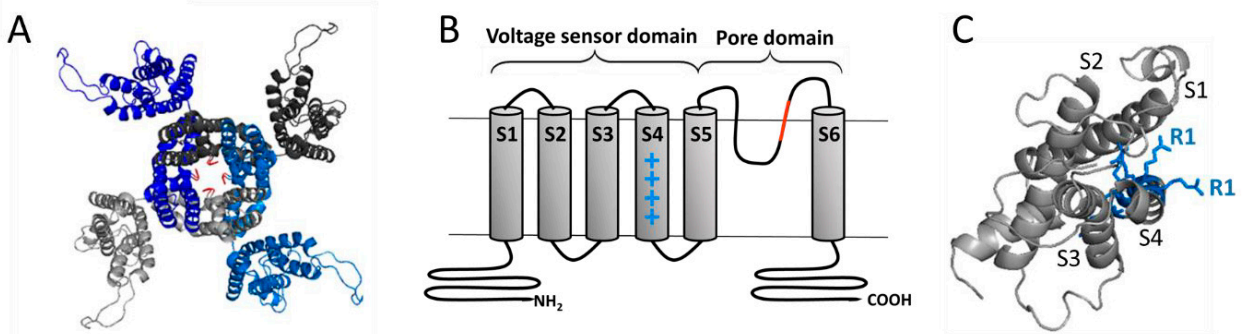

Figure 1. The structure of the Shaker $K_{v}$ channel. A: Four VSD domains (S1-S4) surround a pore domain ( $\mathrm{S}_{5}-$ S6), selectivity filter in red, B: Cartoon of S1-S6, selectivity filter in red, gating charges in blue, C: A VSD (S1-S4) with gating charges in blue, R1 and R2 are the most extracellular gating charges. VSD is seen from the outside of the cell.

\subsubsection{The molecular structure of the Shaker $\mathrm{K}_{\mathrm{v}}$ channel}

In my research, the vast majority of recordings have been done on the Shaker $\mathrm{K}_{\mathrm{v}}$ channel that belongs to the family of so called $\mathrm{K}_{\mathrm{v}} 1$-type channels. The Shaker $\mathrm{K}_{\mathrm{v}}$ channel is natively expressed in the nervous system of Drosophila melanogaster and is named after the hyperexcitable phenotype of flies with nonfunctional channel. The Shaker $\mathrm{K}_{\mathrm{v}}$ channel was the first $\mathrm{K}_{\mathrm{v}}$ channel to be cloned (Papazian et al. 1987, Tempel et al. 1987, Pongs et al. 1988) and is one of the most studied channels. 
The structure of the Shaker $\mathrm{K}_{\mathrm{v}}$ channel is relatively well-known thanks to the large amount of experimental work. In 2005, the structure of the $\mathrm{K}_{\mathrm{v}} 1.2$ channel (also belongs to the family of $\mathrm{K}_{\mathrm{v}} 1$-type channels) was described using X-ray crystallography in a number of papers (Long et al. 2005a, Long et al. 2005b). In 2007, also a crystal structure of a $\mathrm{K}_{\mathrm{v} 1.2 / 2.1}$ chimera was described (Long et al. 2007). Thanks to the large similarity between this chimeric channel and the Shaker $\mathrm{K}_{\mathrm{v}}$ channel, a homology model of the Shaker $\mathrm{K}_{\mathrm{v}}$ channel was built by replacing the side chains of the chimera with the side chains of Shaker (Henrion et al. 2012) . All structures in this thesis are based on this Shaker model.

\subsection{The voltage sensor and voltage sensing in the Shaker $K_{v}$ channel}

A VGIC can occupy three major types of states: closed, open, and inactivated. The unmodified Shaker $\mathrm{K}_{\mathrm{v}}$ channel is classified as an A-type channel: a fast activation is followed by a fast inactivation that terminates the conduction (Hille 2001). The voltage sensor detects and responds to changes in membrane potential. Upon depolarization, the voltage sensor moves through the membrane, resulting in subsequent structural rearrangements of the ion channel, opening the gate and to let ions pass through the pore (Figure 2). I will now describe the voltage sensor and a voltage-sensor cycle for the Shaker $\mathrm{K}_{\mathrm{v}}$ channel.

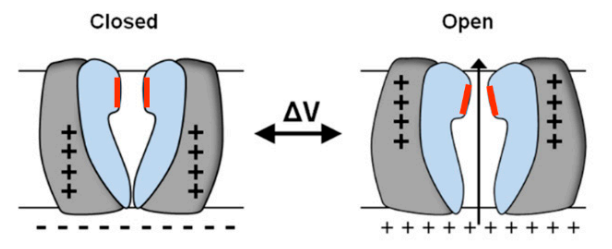

Figure 2. A schematic illustration of the outward movement of $S_{4}$ induced by positive voltages (the selectivity filter in red)

\subsubsection{The gating charges in the voltage sensor makes the channel voltage sensitive}

The VSD and in particular $\mathrm{S} 4$ is crucial for voltage sensing. Already Hodgkin and Huxley predicted that activation of a VGIC must involve movement of charged particles (Hodgkin and Huxley 1952d). In 1973-74, recordings of small asymmetrical capacitive currents, named the gating currents, generated by the movement of these charged particles were published (Armstrong and Bezanilla 1973, Keynes and Rojas 1974). These moving particles were identified as the gating charges (Armstrong and Bezanilla 1974).

The gating-charge distribution of the Shaker $\mathrm{K}_{\mathrm{v}}$ channel follows a well conserved pattern with a positively charged amino acid at every third position in transmembrane helix $\mathrm{S}_{4}$ (starting at residue 362: R1, R2, R3, R4, K5, and R6, see figure $1 \mathrm{C}$ ), as expected for an $\alpha$-helical secondary structure with conserved interactions with negatively charged residues in S1-S3 during gating (Jan and Jan 1990, Keynes and Elinder 1999, Börjesson and Elinder 2008) (Catterall 1986, Guy 
and Seetharamulu 1986). In the following chapter, I describe the importance of these conserved interactions during gating.

\subsubsection{Upward movement of the voltage sensors activates the channel}

The mechanism of voltage sensing and the movement of the voltage sensor have been the focus of intense research for more than half a century, actually since the work of Hodgkin and Huxley on the squid giant axon (Hodgkin and Huxley 1952d). Two different models of voltage-sensor movement were (and still are, to some extent) debated; the helical screw-sliding helix model (Catterall 1986, Guy and Seetharamulu 1986, Keynes and Elinder 1998, Lecar et al. 2003, Yu et al. 2005, Grabe et al. 2007, Tombola et al. 2007) and the voltage-sensor paddle model (Jiang et al. 2003a, Long et al. 2005a, Long et al. 2005b, Long et al. 2007). In the paddle model, S4 is described as moving together with $\mathrm{S}_{3} \mathrm{~b}$, the extracellular half of $\mathrm{S}_{3}$ (Jiang et al. 2003b). Today, the sliding helix has emerged as the consensus model (Vargas et al. 2012).

During activation, defined as the upward movement of $\mathrm{S} 4$, the helix stepwise rotates and translates upward through the membrane, aided by salt bridges between the gating charges and negatively charged residues in S1-S3 (Papazian et al. 1995, Keynes and Elinder 1998, Long et al. 2007, DeCaen et al. 2008, DeCaen et al. 2009). The work by Henrion and colleagues resulted in detailed information about five states of the transition $\left(\mathrm{O}\right.$, and $\mathrm{C}_{1}$ to $\mathrm{C}_{4}$, however the physiological relevance of $\mathrm{C}_{4}$ is doubtful) (Figure 3), and they suggested that $\mathrm{S} 4$ slides at least $12 \AA$ along its axis to open the channel (Henrion et al. 2012). Our knowledge about how the opening of $\mathrm{K}_{\mathrm{v}}$ channels occurs has been essential in my projects to understand how our investigated compounds affect the properties of the Shaker $\mathrm{K}_{\mathrm{v}}$ channel.

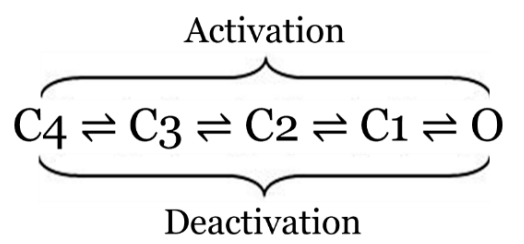

Figure 3. State diagram for a voltage-sensor cycle. C1-C4: closed states, $\mathrm{O}$ : open state

\subsubsection{The last movement of the voltage sensor opens the pore}

To allow the conductance of ions, the internal $\mathbf{S 6}$ gate, and the gates from both fast

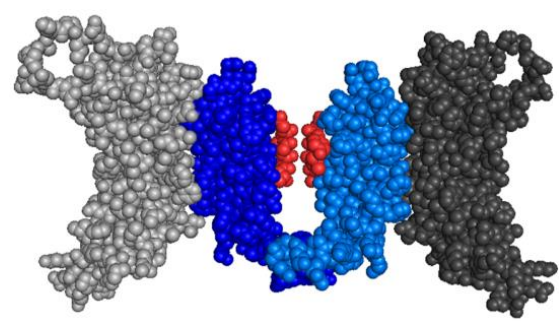

S6 gate

Figure 4. A side-view of the Shaker $K_{v}$ channel, selectivity filter in red. and slow inactivation (see 1.4.4) all need to be open. The S6 gate is formed by an inverted teepee-like arrangement of the S6 helices (Pathak et al. 2005), (Figure 4). The $\mathrm{S} 4$ movement controls the conformation of the $\mathrm{S} 6$ gate by pulling the $\mathrm{S}_{4}-\mathrm{S}_{5}$ linker. However, the mechanistic details for how this electromechanical coupling that cause channel opening remain not fully understood (Blunck and Batulan 2012). 
By introducing three point mutations in the Shaker $\mathrm{K}_{\mathrm{v}}$ structure (generating the Shaker ILT channel), the bulk of gating charge movement becomes energetically separated from channel opening, which is why the steps occur at different voltages. Thereby, it is possible to study the gating charge movement and the electromechanical coupling that opens the S6 gate separately (Webster et al. 2004). The opening has a week voltage dependence, most probably due to a final movement of S4 (Pathak et al. 2005). The Shaker ILT channel has been used in one set of experiments (Paper III).

\subsubsection{The open channel can inactivate by two mechanisms}

Following activation, the unmodified Shaker $\mathrm{K}_{\mathrm{v}}$ channel rapidly (within milliseconds) inactivates by the ball-and-chain mechanism (Armstrong and Bezanilla 1977). This occurs by the occlusion of the ion-conducting pore by an inactivation particle made of the initial 20 amino acids in the N-terminals of the four subunits (Hoshi et al. 1990). The first 11 amino acids are hydrophobic or uncharged and forms a "ball", attached to the channel by a "chain" formed by the nine following amino acids (Hoshi et al. 1990). By deleting amino acid 6-46 of the Shaker channel, this fast inactivation is abolished (Hoshi et al. 1990) and throughout my projects, we have used this modified channel. This $\Delta 6-46$ Shaker $\mathrm{K}_{\mathrm{v}}$ channel is referred to as the Shaker WT channel.

The Shaker $\mathrm{K}_{\mathrm{v}}$ channel can also inactivate by the much slower (within seconds) Ctype inactivation (Hoshi et al. 1991, Larsson and Elinder 2000, Kurata and Fedida 2006). In contrast to the ball-and-chain mechanism, this inactivation is caused by a rearrangement of the selectivity filter (Starkus et al. 1997). The mechanisms behind the C-type inactivation are not fully understood but involve signal transfer between the voltage sensor and the pore domain (Olcese et al. 1997). In addition, our group recently showed that movements in the VSD can affect the pore domain and that the coupling between the voltage sensor and the pore is reciprocal (Conti et al. 2016).

\subsubsection{Downward movement of the voltage sensors closes the channel}

As depolarization activates a VGIC, repolarization deactivates a VGIC. During deactivation, from an activated or inactivated state, $\mathrm{S} 4$ moves back towards the inside of the cell. As during activation, the energy required for this movement is decreased by interactions with acidic residues in S1-S3. The downward movement of $\mathrm{S} 4$ causes a relaxation of the $\mathrm{S}_{4}-\mathrm{S}_{5}$ linker, which in turn causes closure of the $\mathrm{S} 6$ gate. The kinetics and voltage-dependence for deactivation can differ from activation due to hysteresis (reviewed in (Villalba-Galea 2016). For example, long depolarization of the Shaker $\mathrm{K}_{\mathrm{v}}$ channel will dramatically decrease the deactivation rate (Lacroix et al. 2011, Labro et al. 2012). 


\subsection{Modulation of voltage sensing}

In addition to voltage, the activity of VGIC can be modulated by a diversity of molecules and atoms. Actually, VGICs are often dependent on phospholipids (for example PIP2) as cofactors for their physiological function (Suh and Hille 2008). In this chapter, I will describe some modulators, both endogenous (metal ions and PUFAs) and exogenous (pharmaceutical drugs and toxins).

\subsubsection{Metal ions}

As mentioned in the beginning of the Introduction, metal ions have important functions in life (Ringer 1883), and at least 10 metal ions have been classified as essential (reviewed in Elinder and Arhem 2003). Metal ions can affect VGIC by different mechanisms, for instance by directly modifying the channel (blocking or binding to the surface) or indirectly by screening fixed surface charges (Hille et al. 1975, Elinder and Arhem 2003). Group 2 metal ions like $\mathrm{Mg}^{2+}$ seem to affect $\mathrm{K}_{\mathrm{v}}$ channels mainly by the charge-screening mechanism (Elinder and Arhem 2003): when the extracellular concentration of $\mathrm{Mg}^{2+}$ is increased, the negative surface charges are screened and the local electrical potential experienced by the voltage sensor is changed. This results in a shift of voltage dependence of activation (a $G(V)$ shift) towards more positive voltages. Metal ions have been a valuable tool to understand how polyunsaturated fatty acids (PUFAs) modulate the voltage-sensing of a $\mathrm{K}_{\mathrm{v}}$ channel (Börjesson et al. 2008), knowledge that is a part of the basis of my PhD projects.

\subsubsection{Small molecule compounds}

Classical pharmacological drugs block the Nav channels

The Nav channels are classical targets for a variety of pharmacological drugs (Hille 2001) like lidocaine (Figure 5), a local anesthetic. Lidocaine was invented by the chemists Nils Löfgren and Bengt Lundqvist at Stockholm Högskola (later Stockholm University), Sweden, in the 1940 (Löfgren 1948). Lidocaine acts as a Nav-channel blocker and was also used as an antiarrhythmic drug (Southworth 1950, Harrison et al. 1963), and lately also as an antiepileptic drug (AED) in status epilepticus

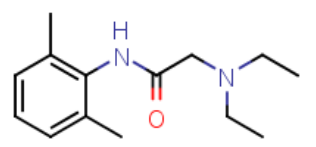

Figure 5. Molecular structure of the $\mathrm{Na}_{v}$ channel blocker lidocaine (Kobayashi et al. 1999, Mori et al. 2004, Zeiler et al. 2015).

Several AEDs like carbamazepine, lamotrigine and phenytoin target the pores of $\mathrm{Na}_{\mathrm{v}}$ channels and stabilize the inactivated channel conformation (Hille 1977a, Hille 1977b, Ragsdale et al. 1996, Rogawski and Loscher 2004). 
The basis for this mechanism is described by the so called modulated receptor hypothesis implying that the blockers have different affinities to different functional states of the channel (closed state: lowest affinity, open state: medium affinity, inactivated state: highest affinity) (Hille 1977a, Hondeghem and Katzung 1977).

\section{$K_{v}$ channels as new targets for antiepileptic drugs}

As discussed in the beginning of this Introduction, there is a great demand for new AEDs to help patients suffering from pharmacoresistant or intractable epilepsy and/or adverse effects (Sankar and Holmes 2004, Loring et al. 2007). In addition to the classical pharmacological approach to blocking $\mathrm{Na}_{\mathrm{v}}$ channels, the excitatory currents can also be reduced by activation of $\mathrm{K}_{\mathrm{v}}$ channels. Lately, the search for new antiepileptic drugs has focused on $\mathrm{K}_{\mathrm{v}}$ channel modulators.

In 2011, the European Medicine Agency and the United States Food and Drug Administration approved Retigabine (Figure 6) as the first antiepileptic drug that acts via activation of $\mathrm{K}_{\mathrm{v}}$ channels (Rundfeldt 1997). Retigabine targets the pore domain of the $\mathrm{K}_{\mathrm{v}} 7.2-5$ channels (Wuttke et al. 2005). Various combinations of the $K_{v} 7.2-5$ subunits (primarily 7.2/3) form the channel

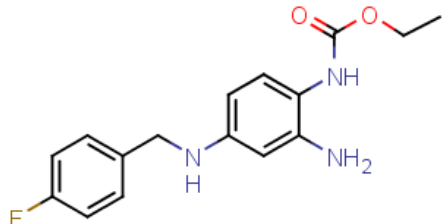

Figure 6. Molecular structure of the $K_{v}$ channel opener Retigabine conducting the M-current that regulates spike frequency adaptation and repetitive firing (Main et al. 2000, Yue and Yaari 2004, Barrese et al. 2010). Retigabine activates the channel by a $G(V)$ shift to more negative voltages (Wuttke et al. 2005). The compound has a low selectivity between the $\mathrm{K}_{\mathrm{v}} 7.2-$ 5 subunits, causing secondary effects (Brickel et al. 2012). Due to multiple case reports of long-term toxicity, Retigabine's clinical application became restricted to patients suffering from pharmacoresistance (Garin Shkolnik et al. 2014, Clark et al. 2015). In 2016, GlaxoSmithKline declared that the production will be discontinued after June 2017 and the product will no longer be commercially available (GlaxoSmithKline 2016). Several research groups are searching for retigabine analogues and other small-molecule compounds with a high selectivity to the $\mathrm{K}_{\mathrm{v}} 7.2 / 3$ channel to reduce the risk of adverse effects (Wickenden et al. 2008, Peretz et al. 2010, Hu et al. 2013, Yue et al. 2016, Wang et al. 2017).

\subsubsection{Toxins}

Voltage-gated ion channels are specific targets for a number of toxins produced by plants and animals to defend themselves or to paralyze a prey (Swartz 2007). Toxins have been a useful tool for studying ion channel structure and function, an example was a scorpion toxin, agitoxin, used to show that $\mathrm{K}_{\mathrm{v}}$ channels are tetramers (MacKinnon 1991). 
Toxins act by different mechanisms of action and the effect of toxins is probably most well studied on $\mathrm{Na}_{\mathrm{v}}$ channels. For the $\mathrm{Na}_{\mathrm{v}}$ channels, there seem to be six main sites (site-1 to 6) of interaction for neurotoxins (Catterall 1980, Catterall et al. 2007)). From these sites, the toxins act by three general mechanisms of actions: pore block from the extracellular side (site-1), allosteric modification of a variety of channel properties (ex. single-channel conductance, and gating) by binding to a site close to the gate (site-2 and 5), and voltage-sensor trapping by binding to the extracellular S3-S4 linker (site-3, 4, and 6) (Börjesson and Elinder 2008). Tetrodotoxin (TTX) and saxitoxin (STX) are classical examples of $\mathrm{Na}_{\mathrm{v}}$ channel blockers (site-1).

Charybdotoxin (a scorpion venom) has been described as a corresponding $\mathrm{K}$ channel (the BK channel) pore blocker (Miller et al. 1985). Site-2, and 5 seem to be unique for the $\mathrm{Na}_{\mathrm{v}}$ channels (Börjesson and Elinder 2008).

There are voltage-sensor trapping toxins targeting $\mathrm{Na}_{\mathrm{v}}, \mathrm{K}_{\mathrm{v}}$, or $\mathrm{Ca}_{\mathrm{v}}$ channels (Swartz 2007). For example, $\alpha$-Scorpion toxins, Sea Anemone toxins, and the tarantula toxin JZTX-I binds to the $\mathrm{S}_{3}-\mathrm{S} 4$ loop in domain IV of $\mathrm{Na}_{\mathrm{v}}$ channels and prevents the upward movement of domain IV-S4 that inactivate the channel (Rogers et al. 1996, Xiao et al. 2005). Hanatoxin, a tarantula-toxin, inhibits the $\mathrm{K}_{\mathrm{v}} 2.1$ channel (Swartz and MacKinnon 1995) and the binding site was mapped to the four VSDs (Swartz and MacKinnon 1997). Today, a growing number of related tarantula toxins have been shown to inhibit activation of $\mathrm{K}_{\mathrm{v}}$ channels (reviewed in (Swartz 2007)). Intriguingly, Hanatoxin also acts as an opener of the Shaker $\mathrm{K}_{\mathrm{v}}$ channel, acting at the corresponding site as in $\mathrm{K}_{\mathrm{v}} 2.1$ channels (Milescu et al. 2013).

These toxins elucidate the VSD as an interesting target for ion channel modification.

\subsubsection{Polyunsaturated fatty acids}

Naturally occurring PUFAs (Figure 7) have important physiological functions, and they act on most ion channels (Boland and Drzewiecki 2008, Börjesson and Elinder 2008, Elinder and Liin 2017). The beneficial effects of PUFAs on cardiac arrhythmia and epilepsy were described more than 30 years ago (McLennan et al. 1985, Hock et al. 1990, Billman et al. 1994, Xiao and Li 1999, Spector 2001). PUFAs potency to regulate neuronal excitability has been suggested to origin from their ability to close sodium- and calcium channels (Vreugdenhil et al. 1996, Tigerholm et al. 2012) in addition to open potassium channels (Börjesson and Elinder 2008, Börjesson et al. 2008, Xu et al. 2008, Börjesson et al. 2010, Börjesson and Elinder 2011, Liin et al. 2016, Elinder and Liin 2017).

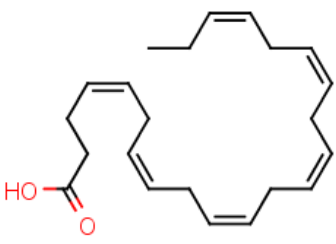

Figure 7. Molecular structure of the PUFA docosahexaenoic acid

In an extensive review by Elinder and Liin (Elinder and Liin 2017), some effects of fatty acids on ion channels appear to be channel specific, whereas three seem to be 
more general: (I) PUFAs alter the maximal conductance, (II) PUFAs alters the kinetics, and (III) PUFAs shift the $G(V)$ and/or inactivation in negative direction along the voltage axis. The $G(V)$ shift will open the channel, and the shift of inactivation will close the channel. For Nav and Cav channels, the $G(V)$ shifting effects by PUFAs seem larger on inactivation than activation, which is why PUFAs generally inhibit these channels. In contrast, $\mathrm{K}_{\mathrm{v}}$ channels are normally activated by PUFAs.

In the review by Elinder and Liin (Elinder and Liin 2017), five VGIC binding sites were suggested, where one is between the extracellular leaflet of the lipid bilayer and S4 (Börjesson and Elinder 2011, Yazdi et al. 2016). Our research group has characterized the effects of PUFAs binding to this site at the Shaker $\mathrm{K}_{\mathrm{v}}$ channel (Börjesson et al. 2008, Xu et al. 2008, Börjesson et al. 2010, Börjesson and Elinder 2011, Tigerholm et al. 2012, Ottosson et al. 2014 (Paper I), Yazdi et al. 2016) and lately also at the $\mathrm{K}_{\mathrm{v}} 7$ channels (Liin et al. 2015, Liin et al. 2016). When bound, PUFAs modify the voltage-dependence of activation, and because both the lipophilicity and electrostatic forces are central for the effect, we have called this the lipoelectric mechanism (Börjesson et al. 2008). In the next chapter, I describe this mechanism of action.

\subsection{The lipoelectric mechanism}

\subsubsection{The ketogenic diet and polyunsaturated fatty acids}

The starting point of our investigation of the modulatory effects of PUFAs was the result of contact with child neurologists at Astrid Lindgren Children's hospital treating children with severe intractable epilepsy with a fat-rich ketogenic diet (Xu et al. 2008). The ketogenic diet was early suggested to mimic the seizure-suppressing effects of ketosis, a condition caused by starvation where the source of energy is shifted from glucose to fatty acids (Wilder 1921). The ketogenic diet results in increased PUFA concentrations in blood serum (Fraser et al. 2003) and brain (Taha et al. 2005). At micromolar concentrations, these PUFAs shifted the $G(V)$-curve in the negative direction along the voltage axis, thereby opening the channel (Xu et al. 2008).

\subsubsection{PUFAs modify a $\mathrm{K}_{\mathrm{v}}$ channel by the lipoelectric mechanism}

A PUFA is a carboxylic acid with an aliphatic tail with at least two double bonds. The aliphatic tail makes the PUFAs partly lipophilic (Börjesson et al. 2008). The carboxyl group makes the PUFA partly hydrophilic, and at physiological $\mathrm{pH} 50 \%$ of the PUFAs are negatively charged when bound to the Shaker $\mathrm{K}_{\mathrm{v}}$ channel (Börjesson et al. 2008). The carboxyl group is required to open the channel - the uncharged methylester, lacking the carboxyl group, fails to open the channel (Börjesson et al. 2008). A positively charged PUFA analogue (an arachidonylamine) actually shifts the $G(V)$ in 
the opposite direction and thereby close the Shaker $\mathrm{K}_{\mathrm{v}}$ channel (Börjesson et al. 2010). PUFAs induce a larger shift at more basic pH (Börjesson et al. 2008) and mutations that alter the surface charge of the channel also affect the size of the shift (Börjesson and Elinder 2011). The PUFAs were suggested to bind to a hydrophobic environment and electrostatically tune the $G(V)$ by what we called the lipoelectric hypothesis (Börjesson et al. 2008).

The molecular details for the interaction between PUFA and the Shaker $\mathrm{K}_{\mathrm{v}}$ channel were further investigated and the lipoelectric hypothesis developed into the lipoelectric mechanism. PUFAs open the Shaker $\mathrm{K}_{\mathrm{v}}$ channel by electrostatically tuning the voltage-dependence of the final voltage-sensor movement that is closely linked to channel opening (see Introduction 1.4.3) (Börjesson and Elinder 2011). In 2011, a site of action was suggested (Börjesson and Elinder 2011) that later was validated and refined by molecular dynamics (Yazdi et al. 2016).

\subsubsection{The lipoelectric mechanism as a new pharmacological mechanism}

Can the lipoelectric mechanism cause the anti-excitable properties of PUFAs? If so, small-molecule compounds acting by the lipoelectric mechanism, with higher selectivity to selected ion channels compared to PUFAs (Elinder and Liin 2017), are potential drug candidates. To gain further understanding, the experimentally observed PUFA-induced changes of ion channel activity were evaluated by computer modelling (Tigerholm et al. 2012). Could the PUFAs affect the neuronal excitability of a pyramidal neuron in hippocampal area CA1, and in particular the response to synaptic input of high synchronicity? Pathological models of cellular excitability associated with epilepsy were used, and by modifying the voltage-dependence of activation of A-type $\mathrm{K}_{\mathrm{v}}$ channels, the voltage-dependence of Nav-channels steadystate inactivation, or by hyperpolarizing the cell membrane, hyperexcitability and repetitive firing was prevented in the model. When these three modifications occurred simultaneously, a lower concentration of PUFAs were needed to prevent hyperexcitability (Tigerholm et al. 2012). This computer modelling suggested that the lipoelectric mechanism can cause the anti-excitable properties of PUFAs, and the most powerful protection against hyperexcitability was accomplished by simultaneously targeting several types of ion channels .

Consequently, small-molecule compounds, either acting on a selected ion channel, or on a well-defined population of ion channels via the lipoelectric mechanism, are potential AED candidates. In my projects, we have been looking for such compounds, improved them, characterized their mechanism of action, and also searched for the site of action on the Shaker $\mathrm{K}_{\mathrm{v}}$ channel. In the following chapter, my general and specific aims are presented. 


\section{Aims}

The general aim of the research leading to this thesis was to find and characterize small-molecule compounds that open a $\mathrm{K}_{\mathrm{v}}$ channel. The compounds should regulate the channel's voltage dependence by the lipoelectric mechanism, a powerful pharmacological mechanism of action, making them suitable as drug candidates for treatment of conditions with disturbed excitability.

The specific aims were to:

1. Explore the importance of charges in the top of $\mathrm{S} 4$ and to construct a channel supersensitive to PUFAs (Paper I)

2. Identify and improve small-molecule compounds that act via the lipoelectric mechanism (Paper I-III)

3. Map the binding site for small-molecule compounds from aim 2 on the Shaker $\mathrm{K}_{\mathrm{v}}$ channel (Paper III)

4. Evaluate the pharmacological potency of the small-molecule compounds from aim 2 to reduce neuronal electrical excitability (Paper II) 


\section{Methodology}

In this Methodology section, I primarily focus on the electrophysiological recordings and analysis of ion channels expressed in oocytes from the African clawed frog, Xenopus laevis. For information about the other methods used in Papers II and III, please see the method section of the papers.

\subsection{Mutagenesis}

Throughout the research for this thesis, experiments were performed on the Shaker $\mathrm{H} 4$ channel (Kamb et al. 1987), made incapable of fast inactivation by the $\Delta(6-46)$ deletion (Hoshi et al. 1990). This channel is here called the Shaker WT channel. In Paper I-III, point-mutated Shaker channels were used to study the effect of modifications on the ion-channel structure. The mutagenesis was done as follows: A pair of mismatched primers were designed to introduce the desired mutation into the Shaker channel DNA present in a plasmid (Bluescript II KS(+), QuikChange SiteDirected Mutagenesis kit (Agilent Technologies)). The parental DNA was degraded after the PCR. The PCR product was transfected into competent bacteria. The bacteria were plated and one colony was selected. After further growth (in broth), plasmids were purified and DNA was sequenced to verify the presence of the desired mutation. DNA was linearized (HindIII) and purified prior to transcription ( $\mathrm{T} 7$ mMessage mMachine kit (Ambion, Austin, TX)) to cRNA.

\subsection{Preparation of oocytes and expression of ion channels}

African clawed frogs (Xenopus laevis) were anesthetized with $1.4 \mathrm{~g} / \mathrm{L}$ ethyl 3aminobenzoate methanesulfonate salt (tricaine). After an incision through the abdomen a batch of oocytes was removed. Clusters of oocytes were separated by incubation for $\sim 1.5 \mathrm{~h}$ in a Ca-free O-R2 solution (in mM: $82.5 \mathrm{NaCl}, 2 \mathrm{KCl}, 5 \mathrm{HEPES}$, and $1 \mathrm{MgCl} 2 ; \mathrm{pH}$ adjusted to 7.4 by $\mathrm{NaOH}$ ) containing Liberase Blendzyme. The oocytes were then incubated at $8{ }^{\circ} \mathrm{C}$ in a modified Barth's solution (MBS; in mM: 88 $\mathrm{NaCl}, 1 \mathrm{KCl}, 2.4 \mathrm{NaHCO}_{3}, 15 \mathrm{HEPES}, 0.33 \mathrm{Ca}\left(\mathrm{NO}_{3}\right)_{2}, 0.41 \mathrm{CaCl}_{2}$, and $0.82 \mathrm{MgSO}_{4}$; $\mathrm{pH}$ adjusted to 7.6 by $\mathrm{NaOH})$ supplemented with sodium pyruvate $(2.5 \mathrm{mM})$ for 224 hours before injection. $50 \mathrm{nl}$ of cRNA (50 pg) were injected into each oocyte using a Nanoject injector (Drummond Scientific, Broomall, PA). Injected oocytes were kept at $8{ }^{\circ} \mathrm{C}$ in MBS until one day before electrophysiological recordings, after which they were incubated at $16^{\circ} \mathrm{C}$. All chemicals were supplied from Sigma-Aldrich (Stockholm, Sweden) unless stated otherwise. 


\subsection{Electrophysiological recordings}

Currents were measured with the two-electrode voltage-clamp (TEVC) technique (GeneClamp 500B amplifier, Digidata 1440A digitizer, and pClamp 10 software; Molecular Devices) 1-6 d after injection of RNA. The amplifier's leak and capacitance compensation were used, and currents were low-pass filtered at $5 \mathrm{kHz}$. All experiments were performed at room temperature $\left(20-23^{\circ} \mathrm{C}\right)$. Two glass microelectrodes were inserted into the oocyte using micromanipulators. The microelectrodes were pulled from borosilicate glass, filled with $3 \mathrm{M} \mathrm{KCl}$ and had a resistance of $0.5^{-2} \mathrm{M} \Omega$.

\subsubsection{Bath solutions}

The control solution contained (mM): $88 \mathrm{NaCl}, 1 \mathrm{KCl}, 15$ HEPES, $0.4 \mathrm{CaCl} 2$, and 0.8 $\mathrm{MgCl} 2 \mathrm{pH}$ was adjusted to 7.4 with $\mathrm{NaOH}$, yielding a final sodium concentration of about $100 \mathrm{mM}$. All chemicals in Papers I-III were obtained from Sigma-Aldrich, if not stated otherwise. Control solution was added to the oocyte bath using a gravity driven perfusion system. Compound solution was added to the bath manually with a syringe to avoid binding to the perfusion system (the added volume was several times larger than the bath solution volume).

\subsubsection{TEVC protocols}

All channels were closed when the membrane potential was clamped to $-80 \mathrm{mV}$ and this voltage was set as the holding potential. Currents were evoked from the holding potential of $-80 \mathrm{mV}$ by $80 \mathrm{~ms}$ (Paper I) or $100 \mathrm{~ms}$ long (Paper II and III), $5 \mathrm{mV}$ steps ranging from -80 up to $+50 \mathrm{mV}$ (WT) or $+70 \mathrm{mV}(3 \mathrm{R})$ with two exceptions:

1) The $L_{3} 61 \mathrm{R} / \mathrm{R}_{3} 62 \mathrm{Q}$ mutant opens at more negative voltages than WT: the holding potential was set to $-120 \mathrm{mV}$, and steady-state currents were achieved by stepping to voltages between -100 and $+50 \mathrm{mV}$ in $5 \mathrm{mV}$ increments.

2) The ILT mutant opens with slower kinetics and at more positive voltages than WT: the voltage was set to $-80 \mathrm{mV}$ and steady-state currents were achieved by stepping between -80 and $+160 \mathrm{mV}$ for $300 \mathrm{~ms}$ in $10 \mathrm{mV}$ increments.

The activation pulse was followed by a pulse to $-20 \mathrm{mV}$ (adjusted for some of the mutants) for $20 \mathrm{~ms}$ to analyze closing kinetics. For selected mutants, closing kinetics were further studied by opening the channels (a pulse to $+70 \mathrm{mV}$ for the Shaker $3 \mathrm{R}$ channel and $+50 \mathrm{mV}$ for the Shaker WT channel) for $150-300 \mathrm{~ms}$ followed by stepping the voltage in $5 \mathrm{mV}$ steps ranging from $+70(3 \mathrm{R})$ or +50 (WT) to $-100 \mathrm{mV}$. 
OFF gating currents of the 434-ILT mutant were measured by first stepping to -120 $\mathrm{mV}$ for $100 \mathrm{~ms}$, then to prepulse voltages between $-120 \mathrm{mV}$ and $+10 \mathrm{mV}$ in $5 \mathrm{mV}$ increments, and finally to $-100 \mathrm{mV}$ for $200 \mathrm{~ms}$. Capacitance compensation for the gating current measurements was carried out from a holding potential of o $\mathrm{mV}$.

\subsection{Compounds}

cis-4,7,10,13,16,19 docosahexaenoic acid (DHA) was purchased from Sigma-Aldrich Sweden AB (Stockholm, Sweden). Pure DHA was dissolved in 99.5\% ethanol to a concentration of $100 \mathrm{mM}$ and stored at $-20^{\circ} \mathrm{C}$ until usage.

Arachidonyl amine (AA+) was provided by T. Parkkari (University of Eastern Finland, Kuopio, Finland). For synthesis and handling information, see (Börjesson et al. 2010). For AA+ measurements, cells were preincubated in $1 \mu \mathrm{M}$ indomethacin, and all recording solutions were supplemented with $1 \mu \mathrm{M}$ indomethacin to prevent COX-induced metabolization of AA+ (Börjesson et al. 2008, Börjesson et al. 2010).

In Paper I, the effective DHA, AA+, and PiMA concentrations were assumed to be $70 \%$ of the nominal concentration because of binding to the chamber walls (Börjesson et al. 2008). All concentrations given in Paper I are the effective concentrations. To improve the washout of DHA and PiMA, albumin-supplemented (100 mg/liter) control solution was added manually to the bath, followed by continuous wash by control solution. For low concentrations of DHA, the recovery was almost complete, but for higher concentrations less complete. For $70 \mu \mathrm{M}$ DHA, the recovery ranged from 40 to $85 \%$ for the different mutants.

In Papers $I I$ and $I I I$, the given concentrations are the added concentrations and albumin was not used to improve washout of compounds.

Pimaric acid (PiMA) and isopimaric acid (Iso-PiMA) were purchased from Alomone Labs, abietic acid (AA), and podocarpic acid (PoCA) were obtained from SigmaAldrich, and dehydroabietic acid (DHAA) was obtained from BOC Sciences. These naturally occurring resin acids were of purities higher than 95\% (except AA that was of technical grade, purified before using). PiMA was treated as DHA (however, the stock concentration of PiMA was $50 \mathrm{mM}$ ). Other naturally occurring resin acids and resin-acid derivatives were initially dissolved to $100 \mathrm{mM}$ in DMSO and stored at -20 ${ }^{\circ} \mathrm{C}$.

Resin-acid derivatives were synthesized by Xiongyu Wu, Katinka Ruda, Stefan Svensson, and Peter Konradsson at Linköping University. The synthesis procedures are described in Papers $I I$ and $I I I$. 


\subsection{Data analysis}

The electrophysiological data were processed and analyzed by Clampfit 10.5 (Molecular Devices, LLC.) and GraphPad Prism 5 (GraphPad Software, inc).

\subsubsection{Estimation of the G[V] shift}

The conductance, $G(V)$, was calculated according to a modified Ohm's law:

$$
G(V)=I /\left(V-V_{\text {rev }}\right),
$$

where $I$ is the average current from the steady-state phase at the end of each pulse ( $100 \mathrm{~ms}$ or $200 \mathrm{~ms}$ after onset of pulse), $V$ is the absolute membrane potential, and $V_{\text {rev }}$ is the reversal potential for $\mathrm{K}^{+}$, (set to $-80 \mathrm{mV}$ ).

These data were fitted to the Boltzmann equation

$$
G(V)=A /\left(1+\exp \left(\left(V_{1 / 2}-V\right) / s\right)\right)^{n},
$$

where $A$ is the amplitude of the curve, $V$ is the absolute membrane potential, $V_{1 / 2}$ is the midpoint potential (when $\mathrm{n}=1$ ), $s$ is the slope and $n$ is an exponent set to 4 (Börjesson et al. 2008) .

The most striking effect of the DHAA derivatives and analogues investigated in Paper II and $I I I$, was seen as negative shifts of the $G(V)$ along the voltage axis. If there is no alteration in slope or amplitude, as sometimes reported for polyunsaturated fatty acids (PUFAs) (Xu et al. 2008), the shift can be measured at any level of the $G(V)$ curve, always giving the same results. However, for some compounds and mutated channels the effect cannot be described by a simple shift of the $G(V)$ curve along the voltage axis; there is a combination of an amplitude increase and a shift of the $G(V)$ curve (Ottosson et al. 2014, Ottosson et al. 2015). The shift of the $G(V)$ curve can either be determined by (i) calculating the difference between $\mathrm{V}_{1 / 2}$ in control solution and $\mathrm{V}_{1 / 2}$ in test solution, or by (ii) determining the shift at the foot of the curve without a normalization of the curve (Börjesson et al. 2008). Because our focus has been to find, explore, and design compounds altering excitability, the shift of the foot of the $G(V)$ curve is most important (Börjesson et al. 2008) and therefore we have measured the $G(V)$ shift at the $10 \%$ level of the maximum conductance in control solution (Börjesson et al. 2008). However, the shift is surprisingly insensitive to the method used to determine the shift. 
The "error", depending on what we mean by correct estimation, at the $10 \%$ level compared to the alteration in $\mathrm{V}_{1 / 2}$ can be derived from Eq. 2:

$$
\Delta V_{\text {error }}=s\left(\ln \left(\left(10\left(A_{\text {cmpd }} / A_{\text {cntrr }}\right)\right)^{1 / \mathrm{n}}-1\right)-\ln \left(10^{1 / \mathrm{n}}-1\right)\right)
$$

$A_{\text {cmpd }} / A_{\text {cntrl }}$ is relative effect on $G$ max by the compound. If $s=6 \mathrm{mV}$ and the amplitude is less than doubled $\left(A_{\mathrm{cmpd}} / A_{\mathrm{cntrl}}=2\right)$ the error is less than $2.2 \mathrm{mV}$. Because the amplitude increment in our recordings almost always is smaller, the error is negligible, and thus we used the $10 \%$-level to determine the shift.

\subsubsection{Estimation of the $Q[V]$ shift}

$Q(V)$ was analyzed by integrating the OFF-gating current before and after compound application. The gating charge was normalized (relative to current at $-30 \mathrm{mV}$ ) and plotted against the prepulse voltage.

\subsubsection{Estimation of time constants}

The weighted time constant $\tau$ for opening and closing (when recorded for longer than $20 \mathrm{~ms}$ ) was calculated from a fitted double exponential function

$$
\mathrm{f}(\mathrm{t})=\left(A_{1} * \mathrm{e}^{\wedge}\left(-\mathrm{t} / \tau_{1}\right)\right)+\left(A_{2} * \mathrm{e}^{\wedge}\left(-\mathrm{t} / \tau_{2}\right)\right)+C, \quad \text { (Eq. 4) }
$$

where $\mathrm{t}$ is the time, $A_{1}$ and $A_{2}$ are amplitudes, $\tau_{1}$ and $\tau_{2}$ are time constants, and $C \mathrm{a}$ constant. The function was fitted to each current sweep (Clampfit 10.5, LevenbergMarquardt search method (Precision: $10^{-6}$ ) with maximum 5000 iterations). The weighted $\tau$ value was calculated as described by

$$
\tau_{\text {weighted }}=\left(\left(A_{1} * \tau_{1}\right)+\left(A_{2} * \tau_{2}\right)\right) /\left(A_{1}+A_{2}\right)
$$

The error was calculated according to propagation of error. The time constant $\tau$ for closing (20 ms) was calculated from a fitted single-exponential function

$$
\mathrm{f}(\mathrm{t})=\left(A_{1} * \mathrm{e}^{\wedge}\left(-\mathrm{t} / \tau_{1}\right)\right)+C .
$$

The function was fitted to each tail current sweep (Clampfit 10.5, LevenbergMarquardt search method (Precision $10^{-6}$ with maximum 5000 iterations).

\subsubsection{Chemical properties of the compounds}

Marvin was used for drawing, and characterizing calculations of chemical structures, Marvin 16.12.9, 2016, ChemAxon (http://www.chemaxon.com). 
$\mathrm{p} K_{\mathrm{a}}$ values (for the acids) were calculated using Calculation Plugin, Marvin 16.12.9, 2016, ChemAxon. Mode: macro; Acid/base prefix: dynamic; Min basic $\mathrm{p} K_{\mathrm{a}}:-5$; Max acidic $\mathrm{p} K \mathrm{a}: 12$; Temperature (K): 298; Correction library: used.

$\log \mathrm{P}$ values were used as a measure of lipophilicity, and values were calculated using Calculation Plugin, Marvin 16.12.9, 2016, ChemAxon. Method: Consensus; Electrolyte concentrations: $0.1 \mathrm{~mol} / \mathrm{dm}^{3}$, values were calculated for the compounds as uncharged. A low $\log \mathrm{P}$ value indicates a low lipophilicity.

\subsubsection{Molecular docking and dynamics}

Molecular docking and molecular dynamics were performed by Samira Yazdi and Erik Lindahl at Stockholm University, Sweden.

For the docking, an open-state model of the Shaker WT channel was built from the $\mathrm{K}_{1}$ 1.2/2.1 chimera (PDB 2R9R) and relaxed in a pure POPC bilayer with parameters and setup as previously described (Yazdi et al. 2016). The most potent compound, Wu122, was used for the docking study. A single subunit was used for docking, removing water, ions and lipids present in the simulation. Asp, Glu, Arg, and Lys residues had protonation states corresponding to $\mathrm{pH} 7$, while His residues were neutral with protonation determined by the local hydrogen bonding network.

Wu122 was docked to three distinct putative binding sites at different vertical positions along the $\mathrm{S}_{3}-\mathrm{S} 4$ cleft. The three top-ranked docked poses based on their predicted energy scores were selected for evaluation using molecular dynamics. For detailed information about docking methodology, see Paper III.

To investigate a preferred binding mode and define the binding pocket, the docked poses of Wu122 were subjected to molecular dynamics simulations of the full shaker tetramer in the POPC bilayer (Yazdi et al. 2016). To enhance sampling of preferred channel-ligand poses, each Wu122 pose was copied to all subunits of the channel. This resulted in three different systems, with each system containing a tetrameric shaker channel and four Wu122 molecules in different positions along the vertical axis of the $\mathrm{S}_{3}-\mathrm{S} 4$ cavity, surrounded with 430 POPC lipids. The systems were first equilibrated in two steps (with restraints, $100 \mathrm{~ns}$ long each). Finally, all restraints were removed and the systems were simulated for $200 \mathrm{~ns}$. For detailed information about dynamic simulations methodology, see Paper III.

\subsection{Statistical analysis}

When comparing two compound-induced shifts a two-tailed unpaired t-test was used. When comparing compound-induced shifts with control one-way ANOVA together with Dunnett's multiple comparison test was used. 
When comparing groups, one-way ANOVA together with Bonferroni's multiple comparison tests was used. Correlation analysis was done by Pearson's correlation test and linear regression. $\mathrm{P}<0.05$ is considered significant for all tests. Average values are expressed as mean \pm SEM.

In Papers I-III, the parametric one-way ANOVA and t-tests have been used and these tests depend on the assumption that the data are sampled from a Gaussian distribution. There are several tests (for example the D'Agostino \& Pearson omnibus normality test) to test if the data are consistent with a Gaussian distribution. These tests require at least eight or more recordings and all data sets $(n=5)$ with eight or more recordings pass the $\mathrm{D}^{\prime}$ Agostino \& Pearson omnibus normality test $(\mathrm{P}>0.05)$

We have set $\mathrm{n} \geq 4$ as a lower limit for the number of recordings and we also expect these to follow a Gaussian distribution. Thus, parametric and not non-parametric tests have been used throughout the projects. 


\section{Results and discussion}

As I noted in the Introduction, (1.5.4), PUFAs have beneficial effects on cardiac arrhythmia and epilepsy, and their ability to modify VGICs has been suggested as an important cause of these effects. PUFAs modify VGIC by the lipoelectric mechanism, but their biological promiscuity makes it complicated to transform them into pharmaceutical drugs (Elinder and Liin 2017). The general aim of the research leading to this thesis was to find and characterize small-molecule compounds opening a $\mathrm{K}_{\mathrm{v}}$ channel by the lipoelectric mechanism. We constructed an ion channel with increased $G(V)$ shifting effects by PUFAs and this channel was a powerful tool in our search and characterization of such small-molecule compounds. In this chapter, I will describe and discuss our findings. I have organized this chapter after the aims, one section per aim.

\subsection{Aim 1: To explore the importance of charges in the top of S4 and to construct a channel supersensitive to PUFAs}

We have known since the start of my research that introduction of charges in the VSD can change the $G(V)$ shifting effects by the PUFA docosahexaenoic acid (DHA) (Börjesson and Elinder 2011). In my first project, we systematically explored the effect of charged residues in the top of $\mathrm{S}_{4}$ (residues 356-362) of the Shaker $\mathrm{K}_{\mathrm{v}}$ channel. All residues in the WT channel, except 357 and 362, had a relatively short hydrophobic side chain. 357 is also relatively short, but a hydroxyl group makes it polar. 362 is the uppermost gating charge (an arginine called R1) of the Shaker $\mathrm{K}_{\mathrm{v}}$ channel voltage sensor.

\subsubsection{Modifications of the charge pattern altered the PUFA-induced G[V] shift} We mutated one residue at a time to arginine, and as background we used $\mathrm{R}_{3} 62 \mathrm{Q}$, a channel without charges in this part of the channel (Paper I). Compared with $\mathrm{R}_{362 \mathrm{Q}}$, the $G(V)$-shifting effect of DHA was altered as follows: an arginine at 359 or 360 increased the absolute shift, an arginine at 356, 358, or 362 did not affect the shift, and an arginine at 357 or 361 abolished the shift (Paper I). The charge modification also altered the voltage-dependence of activation (V5O) and there was a correlation between $\mathrm{V}_{50}$ and DHA-induced $G(V)$ shifts (Figure $8 \mathrm{~A}$ ), suggesting that, at least to some extent, they are caused by the same mechanisms.

If the introduced arginines do not modify the binding of DHA, but electrostatically modify the $G(V)$ shifting effects by DHA, an alteration of the charge distribution in the top of $\mathrm{S} 4$ should affect the $G(V)$ shifting effects by DHA in a systematic way. The specific pattern of the DHA-induced $G(V)$ shifts supports an electrostatic modification (Figure 2E in Paper I): an arginine in a position rotating away from a 
tentative DHA-binding site (i.e. 357 and 361) counteracts the opening effect of DHA, and an arginine rotating towards the site (i.e. 359 and 360) promotes the opening effect of DHA (Figure $3 \mathrm{~F}$ in Paper I).

However, the correlation between $\mathrm{V}_{50}$ and $G(V)$ shift could also occur due to a change in local $\mathrm{pH}$ or due to a mutation-induced change of energy barrier between the states (open and closed). The latter would be reflected in a correlation between the slopes of the fitted Boltzmann curves and the induced $G(V)$ shift (DHA should have large $G(V)$ shifting effects on a channel with a low slope value). Despite slopes in the range from 5.5 (WT) to 15.2 (L358R/R362Q) there was no such correlation (Figure 8B).
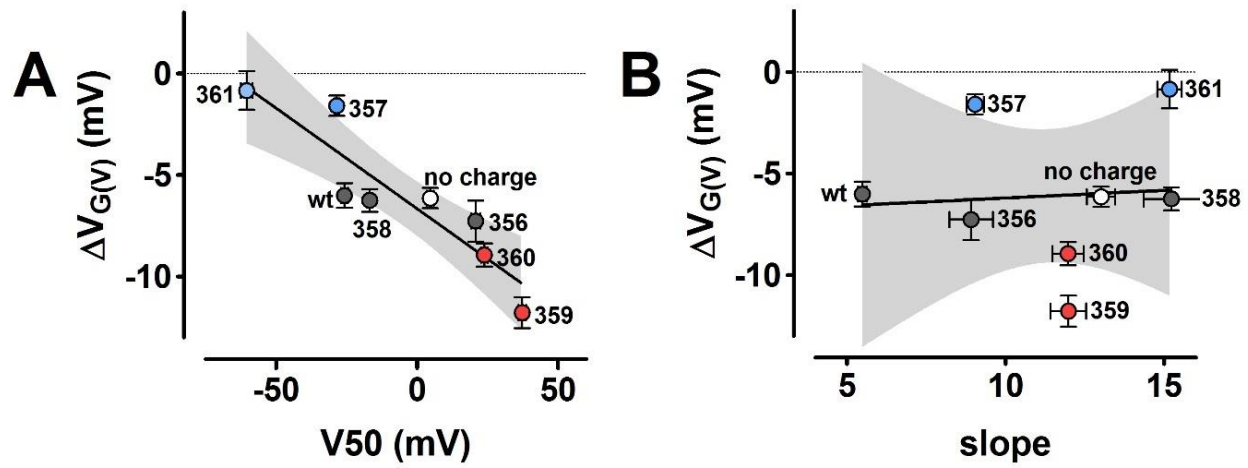

Figure 8. G(V) shift induced by $100 \mu \mathrm{M}$ DHA at pH $7.4 \mathrm{vs}$ V5o (A) and slope of fitted Boltzmann (B). The symbols denote mean $\pm S E M$, color coded according to difference to control $(R 362 Q$, white) grey: no difference, blue: smaller shift, red: larger shift. Black lines denote linear regression, grey shadowed area denote the $95 \%$ confidence interval.

The electrostatic mechanism described above was supported by glutamate mutants. A glutamate in position 359, reduced the DHA-induced $G(V)$ shift compared with the electroneutral S4 top (Figure 3 in Paper $I$ ). When we replaced DHA with a positively charged DHA-analogue (AA+), a glutamate in position 359 promoted opening (Figure $\mathrm{S}_{3}$ in Paper I). In conclusion, our data suggested that the voltage sensor $\mathrm{S}_{4}$ rotates in the last step to open the channel and that DHA electrostatically affects this rotation (Figure $3 \mathrm{~F}$ in Paper $I$ ).

\subsubsection{Combinations of charged residues potentiated the DHA-induced G[V] shift}

Since one of our aims was to construct a Shaker $\mathrm{K}_{\mathrm{v}}$ channel with increased $G(V)$ shifting effect of DHA, we simultaneously introduced several (two to four) arginines in the top of S4 (Figure 4 and 5 in Paper I). According to the results from the singlecharge mutants, a charge at 359 or 360 was the most beneficial for a large $G(V)$ shifting effect by DHA (Figure 8, and Figure 2D in Paper I). Interestingly, when we combined a charge at these two residues (A359R/I36oR/R362Q), the DHA effect of the channel was almost abolished (Figure 4 in Paper $I$ ). When several arginines are combined, the effects are not additive. 
The Shaker $\mathrm{K}_{\mathrm{v}}$ channel mutant with the most beneficial combination of arginines with respect to the DHA-induced $G(V)$ shift has arginines in positions 356,359 , and 362 (M356R/A359R/R362R) (Figure 5 in Paper I). Throughout my thesis work, we have called this channel the $3 \mathrm{R}$ channel, since all three charges are required to maximize the $G(V)$ shifting effect of DHA (Paper $I)$. 356, 359, and 362 are distributed along $\mathrm{S}_{4}$ to elongate the one-arginine-in-every-third position of $\mathrm{S}_{4}$ (R362, R365, R368, R371, K374, and R377).

For the $3 \mathrm{R}$ channel, the effect of DHA was also largely potentiated at $\mathrm{pH} 9$ compared with the Shaker WT and R362Q channels ((Börjesson et al. 2008) and Figure 6A-C in Paper $I$ ) indicating that the increased $G(V)$ shifting effect of DHA not is caused by change in local $\mathrm{pH}$.

My first aim was to investigate the importance of charges in the top of $\mathrm{S}_{4}$ for the lipoelectric mechanism, and to construct a channel with increased $G(V)$ shifting effects by DHA compared to the Shaker WT channel. In summary a positive charge moving away from the suggested binding site counteracts the opening effect of DHA. Contrarily, a positive charge moving towards the suggested binding site promotes the opening effect of DHA. By combining positive charges at positions 356,359 , and 362 , we designed the Shaker $3 \mathrm{R}$ channel, supersensitive to the $G(V)$ shifting effect by DHA. This channel served as an important tool in our search and characterization of other compounds acting by the lipoelectric mechanism.

\subsection{Aim 2: To identify and improve small-molecule compounds that act by the lipoelectric mechanism}

DHA and other PUFAs have promising anti-excitable effects on the Shaker $\mathrm{K}_{\mathrm{v}}$ channel (Börjesson et al. 2008, Xu et al. 2008, Börjesson et al. 2010, Börjesson and Elinder 2011, Tigerholm et al. 2012) and in other biological systems (Elinder and Liin 2017) but their biological promiscuity undermines them as candidates for drug development. Therefore, we searched for small-molecule compounds having the same $G(V)$ shifting effect as PUFAs on the Shaker $\mathrm{K}_{\mathrm{v}}$ channel.

\subsubsection{Pimaric acid is a Shaker $\mathrm{K}_{\mathrm{v}}$ channel opener}

One of the compounds tested was pimaric acid, PiMA (Figure 9), an amphipathic naturally occurring tree-resin acid. When applied to the Shaker WT channel, $100 \mu \mathrm{M}$ PiMA at $\mathrm{pH} 7.4$ induced a $G(V)$ shift of $-4.6 \mathrm{mV}$ (Paper I). As for DHA, the shift was increased when tested on the Shaker $3 \mathrm{R}$ channel $(-10.4 \mathrm{mV})$ and increased further at basic $\mathrm{pH}(-8.4 \mathrm{mV}$ and $-27.9 \mathrm{mV}$ for the Shaker WT and $3 \mathrm{R}$ channels respectively, Figure 7 in Paper I).

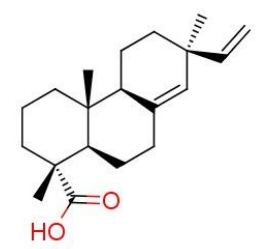

Figure 9. Molecular structure of Pimaric acid. 
These results indicated that PiMA acted by the lipoelectric mechanism and could possibly act as a novel scaffold for Shaker $\mathrm{K}_{\mathrm{v}}$ channel openers.

Like DHA, PiMA has a carboxyl group in one end, and the calculated $\mathrm{p} K_{\mathrm{a}}$ value is almost identical to that of DHA (table S1 in Paper III). Instead of the acyl chain as a lipophilic part, PiMA has a three-ring structure with three methyl- and one vinyl group.

Naturally, resin acids are essential components of tree resins and the proportion of resin acids differs among conifers but is generally as high as $20-50 \%$. The trees use resins as a defense and the concentration is known to increase in infected trees, probably since it is toxic both to beetles and fungi (Beath 1912, Norin and Winell 1971, San Feliciano et al. 1993, Gonzalez 2015).

\subsubsection{Podocarpic acid did not open the Shaker $\mathrm{K}_{\mathrm{v}}$ channel due to a hydroxyl group} The resin acids aroused our curiosity and we continued to investigate four additional naturally occurring resin acids: podocarpic acid (PoCA), iso-pimaric acid (Iso-PiMA), abietic acid (AA), and dehydroabietic acid (DHAA) (Figure 10, and Figure 1 in Paper II). Like PiMA, Iso-PiMA, and DHAA induced a $G(V)$ shift when applied to the Shaker WT channel (100 $\mu \mathrm{M}$ at $\mathrm{pH}$ 7.4), and the $G(V)$ shifts were increased by a factor of 3-4 on the Shaker 3R channel. AA did not induce a $G(V)$ shift on the Shaker WT but on the Shaker $3 \mathrm{R}$ channel, PoCA did not induce a shift on the Shaker WT nor on the Shaker $3 \mathrm{R}$ channel (Figure 1 in Paper II). We synthesized several PoCA derivatives (Table $\mathrm{S} 1$ in Paper III) and the hydroxyl group at C12 makes PoCA an inefficient Shaker $\mathrm{K}_{\mathrm{v}}$ channel opener (Figure $\mathrm{S} 1$ in Paper II).
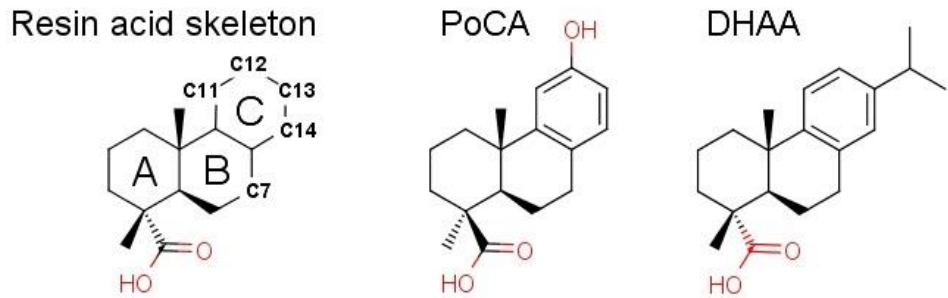

Figure 10. Left: Basic skeleton of resin acids. $A, B$, and $C$ refers to the rings; $C 7$, and C11-C14 refers to the carbon atom. Molecular structures of podocarpic acid (PoCA, middle) and dehydroabietic acid (DHAA, right).

\subsubsection{Dehydroabietic acid was selected as our main scaffold for derivatives}

Our hypothesis was that the lipophilic three-ring structure of the resin acid is incorporated into the membrane close to the voltage sensor and that the carboxyl group from this position electrostatically modifies the gating. Thereby, we predict that both the acidity and lipophilicity of the compounds are crucial for the effect. 
PiMA, Iso-PiMA, and DHAA fulfilled our basic qualifications as a potential candidate: they all induced a shift on the Shaker WT and were more efficient on the Shaker $3 \mathrm{R}$ channel (Figure 1 in Paper I). We selected DHAA as our main candidate and 100 derivatives have been synthesized and characterized.

DHAA has a benzene as C-ring (like PoCA), and an isopropyl attached to C13 (Figure 10). The isopropyl shifts the $\log P$ value (see details in Methodology section, 3.5.4) from 4.5 to 5.75 . Actually, DHAA had the highest $\log P$ value of the tested naturally occurring resin acids (Table $\mathrm{S} 1$ in Paper III). On the contrary, the calculated $\mathrm{p} K_{\mathrm{a}}$ values (see details in Methodology section, 3.5.4) did not differ much between the tested naturally occurring resin acids (Table $\mathrm{S} 1$ in Paper III). The importance of these chemical properties is further discussed in the next sections.

\subsubsection{Side chains at the B-ring affected chemical and ion-channel opening properties}

In the attempt to increase the $G(V)$ shifting effect of DHAA, we introduced side chains at $\mathrm{C}_{7}$ (Figure 10A and Figure 2 in Paper II). Some of the side chains made the compound more acidic (reduced $\mathrm{p} K_{\mathrm{a}}$ value, Figure $11 \mathrm{~A}$ ), a property expected to increase the $G(V)$ shifting effect. A small, hydrophilic side chain, as a carbonyl (Wu35), or an oxime (Wu31) made the compounds more acidic but reduced the $G(V)$ shifting effect. Likewise, a long and bulky propylbenzene oxime (K10) also reduced the $G(V)$-shifting effect but did not alter the $\mathrm{p} K_{\mathrm{a}}$ value. There was no linear relation between the $G(V)$ shifting effect and the $\mathrm{p} K_{\mathrm{a}}$ value (Figure $11 \mathrm{~A}$ ). An allyloxime at $\mathrm{C}_{7}$ gave us a compound with increased efficacy (K8).
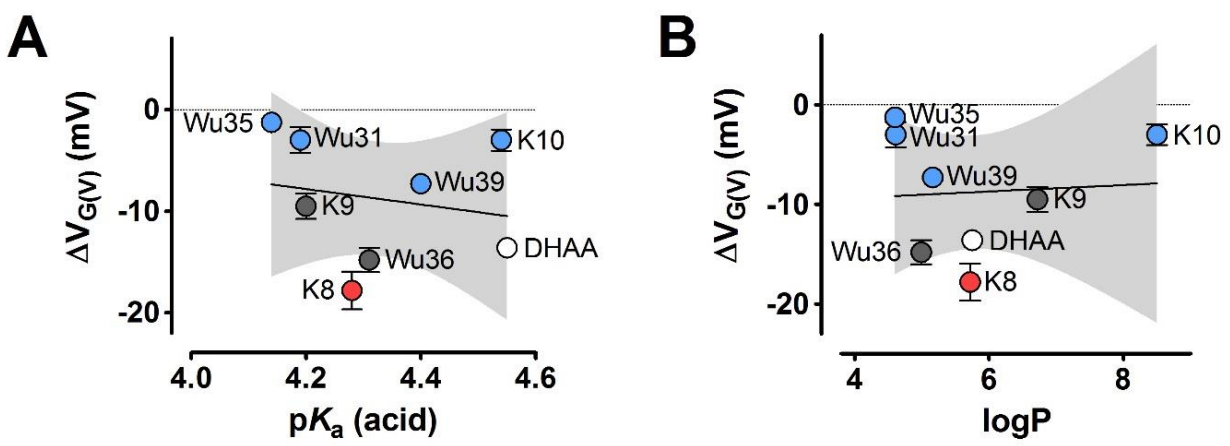

Figure 11. Chemical properties of DHAA-derivatives with a side chain at C7. Compound-induced $G(V)$ shift (10O $\mu M$ at $p H 7.4$ on the Shaker $3 R$ channel) vs $p K a(A)$ and $\log P(B)$. The symbols denote mean $\pm S E M$, color coded according to difference to control for $G(V)$ shift (R362Q, white) grey: no difference, blue: smaller shift, red: larger shift. Black lines denote linear regression, grey shadowed area denote the $95 \%$ confidence interval.

Side chains may also alter the lipophilicity of the compounds. For the allyloxime, the polarity of the oxime is counterbalanced by the nonpolarity of the allyl, making K8 as 
lipophilic as DHAA (Figure 11B). There was no linear relation between the $G(V)$ shifting effect and the $\log \mathrm{P}$ values (Figure 11B), but the compounds inducing the largest $G(V)$ shifts all have a $\log \mathrm{P}$ around six. These derivatives indicate that a side chain at $\mathrm{C}_{7}$ is important, either by making distinct molecular interactions, or by changing the molecular properties (lipophilicity or acidity), or by a combination of them.

\subsubsection{Halogenation of the C-ring affected chemical- and ion channel opening properties}

In the attempt to increase the $G(V)$ shifting effect of DHAA, we also introduced halogens (fluorine $(\mathrm{F})$, chlorine $(\mathrm{Cl})$, bromine $(\mathrm{Br})$, and iodine (I)) into the C-ring. Chlorines were introduced at $\mathrm{C} 11, \mathrm{C} 12$, and $\mathrm{C}_{14}$, at one, two or three positions simultaneously (Figure 3 in Paper II). F, Br, and I were introduced at $\mathrm{C} 12$ and $\mathrm{C} 14$, one at a time (Figure 3 in Paper II). Several derivatives reduced the $G(V)$ shifting effect compared with DHAA, in particular 11-Cl (Wu10o), and 11,12,14-triCl (Wu45). Halogenation ( $\mathrm{F}, \mathrm{Cl}, \mathrm{Br}$, and I) of $\mathrm{C} 12$ had only minor effects, fluorination of $\mathrm{C} 14$ reduced the effect while all other halogens at $\mathrm{C} 14$ increased the effect. Bromination of $\mathrm{C}_{4}$ (Wu26) created the most potent opener among these (Figure 3 in Paper II).

We also synthesized DHAA-derivatives without the isopropyl at C13. When we replaced this isopropyl with a chlorine, in combination with further chlorination of $\mathrm{C} 12$, and $\mathrm{C}_{14}$ (Wu5O), we found one of the most potent derivatives among all tested (Figure 4, and 5 in Paper II).

As for the side chains at $\mathrm{C}_{7}$, the halogen can introduce new noncovalent interactions (halogen bonds) with the surrounding (protein or lipid bilayer). The halogens can also change the chemical properties (acidity and lipophilicity) of the compound. Despite the large distance between the carboxyl group and the C-ring, a halogen in the $\mathrm{C}$-ring will decrease the calculated $\mathrm{p} K_{\mathrm{a}}$ of the carboxyl group (Figure $12 \mathrm{~A}$ ).

Halogenation will actually increase the lipophilicity by a fascinating mechanism that I here will summarize. As electrophiles, halogens cause a polarization of the negative charges in the carbon-halogen bond. The smaller the halogen is, the more polarized the bond will become (the smaller the higher electronegativity). When a halogen is introduced into a benzene ring, the six conjugated electrons from the pi-cloud will therefore redistribute to also partly cover the halogen bond. For the larger halogens, a lone electron pair feeds into the delocalized $\pi$-cloud and, to some extent, offsets the polarization of the bond. The consequence of these electron redistributions is a less polar molecule, and the bigger the halogen is, the less polar it will become. This is reflected in higher lipophilicity in halogenated compounds, and if several halogens are introduced, the effect becomes additive (Figure 12B) (Clugston and Flemming 2000, Cavallo et al. 2016). 

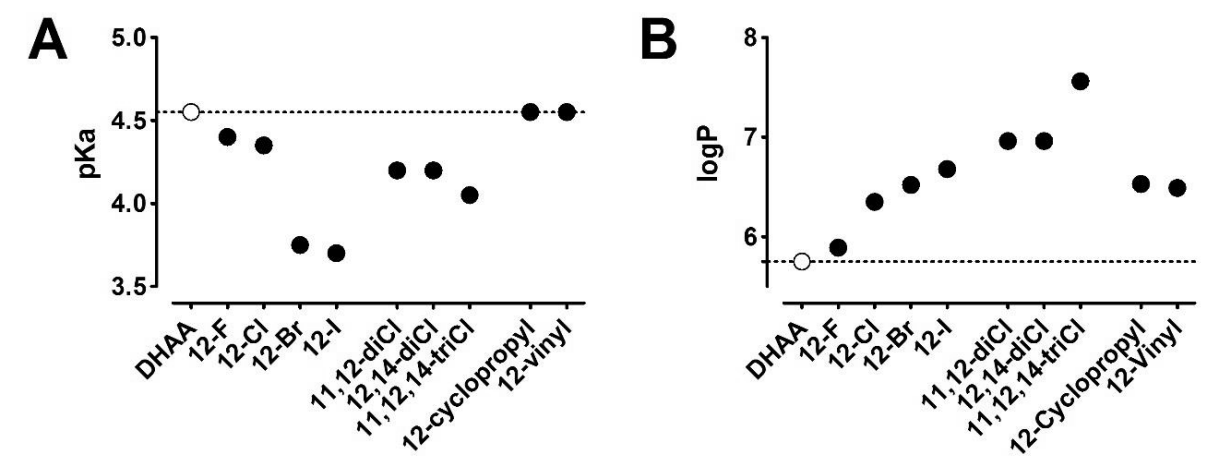

Figure 12. The effects of halogenation of the DHAA C-ring on the acidity (A), and lipophilicity (B).

\subsubsection{Side chains at the B-ring in combination with halogenation of the C-ring potentiated the opening effect}

Halogenation of the C-ring had an impact on the opening efficacy, and so also did specific side chains at $\mathrm{C} 7$. What if we combined these types of modifications? We tested many combinations of $\mathrm{C}_{7}$ side chains and $\mathrm{C}$-ring halogenation and the derivatives' opening efficacy followed a clear pattern (with some exceptions). The most effective openers had a methyl- or allyloxime at $\mathrm{C}_{7}$ and a halogen at $\mathrm{C} 12$ (Figure 3 in Paper II). We identified Wu32 (C7-methyloxime, 12-Br DHAA) as the most efficient opener. Interestingly, a few compounds did not follow the pattern: when a metyloxime was combined with a chlorination of $\mathrm{C} 11$ (Wu105), the compound became an efficient opener.

Also, an iodine at $\mathrm{C} 12$ in combination with a polar oxime (Wu86), or an iodine at $\mathrm{C} 14$ in combination with a carbonyl (ketone) at $\mathrm{C}_{7}$ (Wu68) were surprisingly efficient openers (Figure 3 in Paper II). Obviously, the effects of side chains at $\mathrm{C}_{7}$ and halogenation of the C-ring are not additive (Figure S2 in Paper II). As both the side chains at $\mathrm{C}_{7}$, and halogenation of the $\mathrm{C}$-ring affects acidity and lipophilicity, the chemical properties differed substantially among the derivatives. There was no linear relation between the induced shift and acidity (Figure 13A), nor between the shift and lipophilicity (Figure 13B), however, the most efficient openers all had a $\log \mathrm{P}$ around 6 (Figure 13B). 

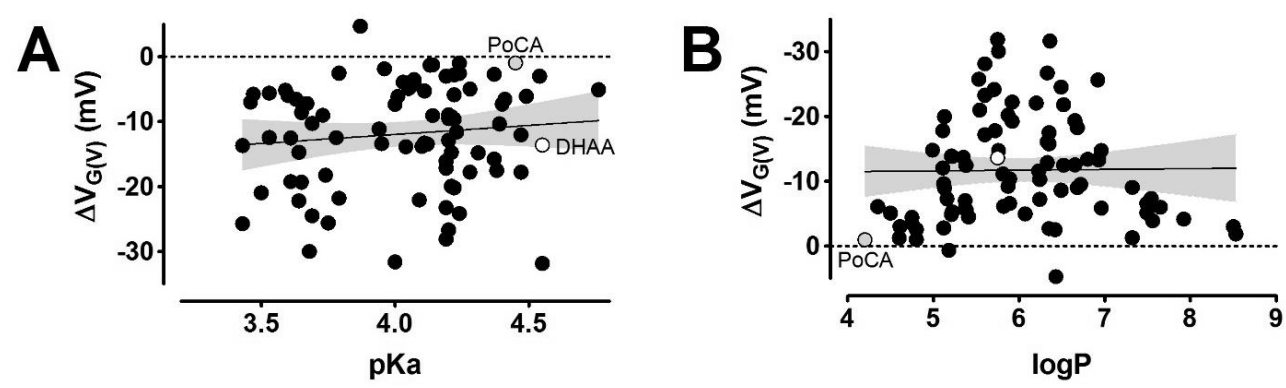

Figure 13. Acidity (A) and lipophilicity (B) vs mean induced $G(V)$-shift (10o $\mu M$ at $p H 7.4$ on the Shaker $3 R$ channel) for halogenated DHAA- and PoCA derivatives with a C7-side chain (10O $\mu \mathrm{M}$ at $\mathrm{pH} 7.4$ ). White circle denote DHAA and grey circle PoCA. Black lines denote linear regression, grey shadowed area denote the 95\% confidence interval.

\subsubsection{Halogens can be replaced with specific hydrocarbons with preserved efficacy}

If the most important function of halogens was to alter the lipophilicity of the compounds, then they should be able to be replaced with lipophilic side chains. In our continued search for compounds with increased efficacy as openers, we replaced the halogens at the C-ring with different side chains, mainly small hydrocarbons (Table S1 in Paper III). When the bromine at $\mathrm{C} 12$ of Wu32 was replaced with a vinyl (Wu119) the efficacy was preserved, and when replaced with a cyclopropyl (Wu122), the efficacy was even increased (Table $\mathrm{S} 1$ in Paper III). Interestingly, the $\log \mathrm{P}$ values for these three derivatives are nearly identical further elucidating the importance of the lipophilicity. These hydrocarbon-derivatives suggested that the effect of halogenation most probably is not due to new bindings but rather is important for the incorporation of the compound to a lipophilic environment (Paper III).

\subsection{Aim 3: To map the Shaker $K_{v}$ channel binding site for small- molecule compounds from aim 2}

We identified and synthesized 125 resin acids and resin-acid derivatives of which several had high efficacy as Shaker $\mathrm{K}_{\mathrm{v}}$ channel opener (Paper I, II, and III). One of the aims of the research leading to this thesis was to find the binding site for these compounds on the Shaker $\mathrm{K}_{\mathrm{v}}$ channel to further understand, and refine them as openers. To find the binding site, we used structural modifications, partly of the channel, and partly of the compounds. Also, we investigated the mechanism of action. If we could understand how these compounds modify the channel, we would also get information about where the modification takes place.

\subsubsection{Resin acids and their derivatives needed to be negatively charged to act as openers}

To open an ion channel by the lipoelectric mechanism, the compound has to be negatively charged (Börjesson et al. 2008, Börjesson et al. 2010, Börjesson and 
Elinder 2011). As for PUFAs, the opening efficacy for resin acids and their derivatives was potentiated at basic compared with neutral pH (Figure 7 in Paper I, Figure 1 and 5 in Paper II). By replacing the carboxyl group with a permanently negatively charged group (Wu164), the efficacy at $\mathrm{pH} 7.4$ became comparable to DHAA at $\mathrm{pH} 9$ (Figure $\mathrm{S}_{5}$ in Paper III). The importance of the charge was further confirmed by a positively charged DHAA-derivative. The carboxyl group was replaced by an amine (Wu165, Figure 4 and Table S1 in Paper III), making the compound positively charged at acidic $\mathrm{pH}$. This compound shifted the $G(V)$ in positive direction along the voltage axis. The effects of Wu164 and Wu165 thus support an electrostatic interaction between the compound and the channel; the charge cannot only play an isolated role for the binding.

\subsubsection{Resin acids and their derivatives acted on the opening step}

During activation, ion channels undergo multiple activation steps prior to channel opening (Armstrong 1981, Zagotta et al. 1994, Delemotte et al. 2011, Henrion et al. 2012). To better understand if the resin acids and their derivatives act on a specific transition, we tested Wu32 on the Shaker ILT-mutant (discussed in the Introduction, section 1.4.3). In this channel, the early, major charge carrying, steps are separated from the last, channel-opening, step (Smith-Maxwell et al. 1998). We found that while the gating currents (reflecting the early steps) were not affected by Wu32, the $G(V)$ (reflecting the last step) was shifted by more than $-60 \mathrm{mV}$ along the voltage axis (Figure 1 in Paper III). This suggests that Wu32 acts on the channel-opening step (Figure 1 in Paper III)). The shift by DHAA was potentiated on the Shaker ILTmutant (Figure S1 in Paper III), suggesting also that DHAA acts on the opening step.

\subsubsection{The most efficient openers also slowed down channel closure}

If a negatively charged compound is introduced close to the voltage sensor and electrostatically modifies the movement of the voltage sensor through the membrane, the kinetics are expected to be slightly modified; the compounds should speed up the opening, and slow down the closing. Both DHA and DHAA had these small effects on the kinetics (Figure 2, S1, and S2 in Paper III). However, we found that several derivatives, like Wu32 and Wu122, slowed down the closing kinetics remarkably more than expected from a purely electrostatic interaction (Figure 1, S1, S4, and S6 in Paper III). This was found for several investigated channels, including the Shaker WT, $3 \mathrm{R}$ and R362Q channels. In addition, the closing kinetics of the Shaker ILT channel was slowed down by Wu32, (but not DHAA), indicating that it is the first transition during closing that is prevented by the derivatives (Paper III).

We investigated the slowing of the closing kinetics for the derivatives inducing a $G(V)$ shift larger than $-20 \mathrm{mV}$ (Figure 2 in Paper III). There were no obvious correlations between side chains or halogenation and the closing kinetics. However, efficient openers with a methyloxime at $\mathrm{C}_{7}$, all seemed to have a large effect on the closing 
kinetics. As for the induced shifts, there seemed to be a certain degree of lipophilicity connected to a large effect on deactivation kinetics (Figure S7 in Paper III). Most probably, this correlation occurs since compounds enough lipophilic also interacts better with channel/gets more easily incorporated into the membrane. In fact, also the positively charged Wu32-analogue slowed down the closing kinetics (and opening, as expected by the opposite electrostatic interaction). We do not know the mechanism of action for this modification of kinetics, but most probably the compounds sterically prevent the downwards movement of the voltage sensor.

\subsubsection{A cysteine-scan identified the $\mathrm{S} 3$ helix as important for the interaction}

The $G(V)$-shifting effect and the slowing of the closing kinetics suggested an interaction site close to the VSD, probably between the $\mathrm{S}_{3}$ and $\mathrm{S}_{4}$ helices (Paper III). To test the involvement of $\mathrm{S}_{3}$, we mutated the extracellular half (residue 318-329) to cysteines. All mutated residues (except $\mathrm{Y}_{32}, \mathrm{~T}_{32} 6$, and $\mathrm{T}_{32}$ ), are hydrophobic in the Shaker WT channel. For five of the residues (318, 320, 322, 324, and 326), a cysteine increased the Wu32-induced $G(V)$ shift. These five residues were clustered

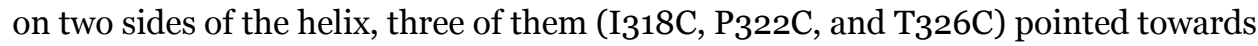
our predicted binding site.

\subsubsection{Molecular docking and molecular dynamics identified a binding site}

The modifications of the compound and channel suggested that there might be a binding site for the resin acids and derivatives in the cleft formed by the $\mathrm{S}_{3}$ - and $\mathrm{S}_{4}$ helices and the lipid bilayer (referred to as the $\mathrm{S}_{3} / \mathrm{S} 4$ cleft) (Paper III). Wu122 was selected for molecular docking (performed by Samira Yazdi and Erik Lindahl at Stockholm University, Sweden) on the Shaker WT channel. The compound was docked on several positions along the $\mathrm{S}_{3} / \mathrm{S}_{4}$ cleft and the docked positions were evaluated by molecular dynamics. A binding site in the top of this cleft was found, with the negative charge of Wu122 pointing towards the top of the cleft (Figure 14, and Figure 3 and $\mathrm{S}_{4}$ in Paper III). The side chain at $\mathrm{C}_{7}$ (methyloxime) pointed into the hydrophobic core between $\mathrm{S}_{3}$ and $\mathrm{S}_{4}$, and the cyclopropyl at C12 pointed towards the lipid membrane (Figure 14).

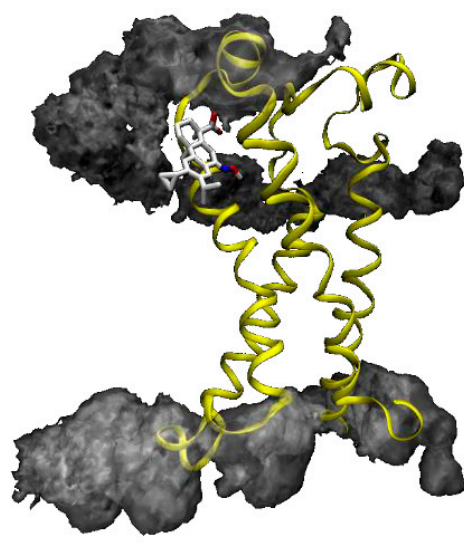

Figure 14. A VSD (yellow) with Wu122 (white) in the binding site suggested from the molecular dynamics. The grey cloud illustrates the lipid membrane.

A number of molecular interactions between Wu122 and the ion channel were identified. The negative cluster in the $\mathrm{S}_{3}-\mathrm{S}_{4}$ loop (333-336) of the Shaker $\mathrm{K}_{\mathrm{v}}$ channel formed salt bridges with the carboxyl group of Wu122, mediated by sodium ions in 
the system (Paper III). Also, hydrogen bonds between the carboxyl group of Wu122, and S351, Q354 (S3-S4 loop), and S357 (top of S4) were found. In addition, a hydrogen bond between the nitrogen in the methyloxime and T329 (top of S3) was identified.

Can Wu122 have this binding site in common with the other resin acids and their derivatives? For example, this position explains the PoCA's non-efficacy as opener (PoCA probably does not bind to the channel since the hydroxyl group would point into the membrane), the importance of a certain lipophilicity (one side of the molecule faces the lipid membrane), and why a hydrogen-bond acceptor in the side chain (like an oxime group) increases the efficacy (hydrogen bond with T329). A common binding site with well-defined contacts with the $\mathrm{S}_{3} / \mathrm{S}_{4}$ cleft are also supported by large differences in $G(V)$ shifting effect by compounds where the only difference is in chirality either at $\mathrm{C}_{7}$ with nitro as side chain (Wu101 vs Wu102) or at the carbon where the carboxyl group is bound (DHAA vs Wu170). Most probably, also the other resin acids and derivatives bind to this site on the Shaker $\mathrm{K}_{\mathrm{v}}$ channel.

\subsubsection{Modifications of the charge pattern supported the suggested binding site} If the resin acids and their derivatives acted by the lipoelectric mechanism from the suggested binding site, an alteration of the charge distribution of the extracellular end of S4 should affect the $G(V)$ shifting effects by resin acid in a systematic way. To explore this, we altered the charge profile of the top of $\mathrm{S} 4$ by introducing arginines, one at a time, at position 356-362 on the R362Q-background (as we did in the characterization of DHA, see 4.1.1) and compared the $G(V)$ shifting effects by DHAA- and Wu32 on these single-charge mutants with R362Q. Intriguingly, both DHAA- and Wu32 induced a relatively large $G(V)$ shift on the R362Q channel ( -4.8 $\mathrm{mV}$ and $-28.9 \mathrm{mV}$ for DHAA and $\mathrm{Wu} 32$ respectively), that maybe can be explained by a sterically modification of the binding pocket when 362 was mutated to glutamine.

Compared with $\mathrm{R} 362 \mathrm{Q}$, an arginine at 359 or 360 increased the $G(V)$-shifting effect of Wu32, an arginine at 356 or 358 did not change the effect, and an arginine at 357, 361, or 362 decreased the effect (Figure 4 in Paper III). These results can be explained by electrostatic interactions between the introduced arginines and the compound if the compound is positioned at the suggested binding site between $\mathrm{S}_{3}$ and $\mathrm{S}_{4}$ : a charge at 359 or 360 promotes opening and rotate $\mathrm{S} 4$ clockwise to open the channel; contrary, a charge at 357,361 , or 362 rotates $\mathrm{S} 4$ counter-clockwise to promote closure of the channel (Paper III). For all investigated channels, there was a strong correlation between the DHAA- and Wu32-induced $G(V)$ shifts, but Wu32 was six times more efficient (Figure 4G in Paper III), suggesting the lipoelectric mechanism as a common mechanism of action and that the suggested binding site is a common binding site for resin acids and their derivatives. 
Thus, we have identified a binding site for the resin acids and their derivatives in the $\mathrm{S}_{3} / \mathrm{S} 4$ cleft, a principally new binding site for small-molecule compounds. Our data strongly suggest that these compounds electrostatically facilitate the last rotational movement of S4 prior to channel opening, consequently, they act by what we have called the lipoelectric mechanism. In addition, several of the most efficient openers also slow down closing kinetics. With these properties, the resin acids and their derivatives can potentially be developed into excitability-reducing compounds.

\subsection{Aim 4: To evaluate the pharmacological potency of the small- molecule compounds from aim 2 to reduce neuronal electrical excitability}

The fourth aim of the research leading to this thesis was to study if these compounds had an effect on neuronal electrical excitability. By making recordings on the Shaker $\mathrm{K}_{\mathrm{v}}$ channel expressed in oocytes from the Xenopus laevis, we get information about the binding site and mechanism of action. To explore if the effects found on the channels expressed in Xenopus oocytes also applies to channels expressed in mammalian cells, we did also express the Shaker $3 \mathrm{R}$ channel in CHO-K1 cell line and tested six structurally different compounds at a concentration of $10 \mu \mathrm{M}$ (Figure $\mathrm{S}_{3}$ in Paper II, performed by Andreas Nolting). We found a linear relation between the shifts in the two cell systems.

The same six compounds were also tested on native dorsal root ganglion (DRG) from mice (performed by Urban Karlsson). All six compounds caused a hyperpolarization of the resting membrane potential (in the range from -1 to $-8 \mathrm{mV}$ ), most probably due to opening of one or several types of K channels. Despite a correlation between shifts induced on the Shaker $3 \mathrm{R}$ channel and hyperpolarization of DRG membrane potential, it was clear that a side chain at $\mathrm{C}_{7}$ did not have the same importance for the effect (Figure 6 in Paper II). Wu32 hyperpolarized the membrane potential by about $-4 \mathrm{mV}$, to be compared with about $-8 \mathrm{mV}$ by Wu5o (12,13,14-triCl DHAA), the most effective compound on the DRG recordings.

To test if the compounds also reduced the neuronal excitability, we stimulated action potential firing in the DRG neurons by a constant current pulse. Wu 35 had the least effect on membrane potential, and did not dampen excitability. In contrast, Wu5o completely abolished all action potentials and the effect was clearly reversible (Paper $I I$ ). Thus, these resin acid derivatives are also able to reduce excitability in neurons. 


\section{Concluding remarks}

In the research leading to this thesis, I have studied compounds modifying the Shaker $\mathrm{K}_{\mathrm{v}}$ channel by the lipoelectric mechanism, first described for PUFAs by our group (Börjesson et al. 2008, Xu et al. 2008, Börjesson et al. 2010, Börjesson and Elinder 2011). PUFAs have been reported to reduce both neuronal and cardiac excitability (reviewed in Elinder and Liin 2017). The site of action for PUFAs on VGIC (Börjesson and Elinder 2011, Yazdi et al. 2016) is in the cleft between $S_{3}$ and $\mathrm{S}_{4}$ and contains a well-conserved region (S4) among VGIC. This suggests that PUFA can modify a diversity of ion channels by the lipoelectric mechanism. This brings the challenge of selectivity if PUFAs are to be developed to pharmaceutical drugs. However, the well-conserved interaction site can also be a large advantage since several ion channels can possibly be targeted. For example, Liin and coworkers have recently described the opening effects of PUFAs and PUFA-analogues on the $\mathrm{K}_{\mathrm{v}} 7.1$ channel co-expressed with the $\beta$-subunit KCNE1, central for the cardiac repolarization (Liin et al. 2015). PUFAs and PUFA-analogues also act on the structurally related $K_{v} 7.2 / 3$ - channel (Liin et al. 2016), important for setting the resting membrane potential in hippocampal and DRG neurons (Jentsch 2000). The beneficial effects of PUFAs and PUFA derivatives on the $\mathrm{K}_{v} 7$ channels further elucidated the potency of the lipoelectric mechanism, and motivated the search for ion-channel selective lipoelectric small-molecule compounds.

\subsection{Functional similarities and differences between PUFAs and resin acids}

My focus have been to find, characterize, and refine small-molecule compounds acting by the lipoelectric mechanism. We aimed to construct a Shaker $\mathrm{K}_{\mathrm{v}}$ channel with increased $G(V)$ shifting effects by DHA since such a channel would give us a robust tool in the search for and characterization of small-molecule compounds. We created the Shaker $3 \mathrm{R}$ channel (M356R/A359R/R362R) which has a modified charge profile in the top of $\mathrm{S} 4$, and our results supported an electrostatic interaction between the compound (DHA or DHA-analogue) and the ion channel, and that the effect was on the last movement of the voltage sensor (Paper I). We used the Shaker $3 \mathrm{R}$ channel in the search for other compounds acting by the lipoelectric mechanism.

We identified the resin acids as Shaker $\mathrm{K}_{\mathrm{v}}$ channel openers; they have a lipophilic part formed by a three-ring structure, and a hydrophilic part formed by a carboxyl group in one end of the molecule (Paper I-III). In total, we tested five naturally occurring resin acids and synthesized 120 resin-acid derivatives and found a clear structure-activity relationships. The charge of the A-ring determines the direction of the $G(V)$ shift. A medium-sized side chain (for example a metyloxime) attached to 
the B-ring, in combination with a medium-sized halogen ( $\mathrm{Cl}$ or $\mathrm{Br}$ ), or a short hydrocarbon chain, attached to the C-ring generally increase the derivatives's efficacy to open the channel. The lipophilicity of the compound appears to be crucial, whilst the (theoretically calculated) $\mathrm{p} K_{\mathrm{a}}$ value has a less predictive power.

There are similarities as well as differences between the PUFAs and the resin acids. Both act electrostatically on the last, channel opening, movement of the voltage sensor. Several resin-acid derivatives, but not the PUFAs, slow down the closing kinetics a whole lot more than expected from an electrostatic interaction. We do not fully understand the mechanism for this allosteric slowing of closing kinetics (Paper III). By modifying the molecular structure of both the channel and the compounds, combined with molecular dynamic simulations, we have found the binding site for the resin acids and derivatives on the Shaker $\mathrm{K}_{\mathrm{v}}$ channel to a pocket formed by the $\mathrm{S}_{3} / \mathrm{S} 4$ cleft and the lipid membrane, partly overlapping the binding site for DHA (Yazdi et al. 2016). However, there are subtle differences in the effects on the array of $\mathrm{S} 4$ mutations, suggesting that the resin acids bind deep in the $\mathrm{S}_{3} / \mathrm{S}_{4}$ cleft while PUFAs possibly bind more superficially.

\subsection{Resin-acid effects on other potassium channels}

Given the similarity in effects and binding site between the resin acids and their derivatives, and the PUFAs, it is possible that other ion channels are also affected by resin acids and their derivatives, similar to the PUFAs which seem to affect almost all channel types (Elinder \& Liin, 2017). Then, as for PUFAs, the selectivity for ion channels can both become a challenge and an advantage in the development of resin acids and their derivatives to pharmaceutical drugs. Small modifications of the molecular structure (such as alterations in chirality) can have a large impact on the $G(V)$ shifting propensity, indicating that it might be possible to design compounds with selectivity for specific ion channels. Some resin acids and their derivatives also target the calcium- and voltage-sensitive BK channel (Imaizumi 2002, Ohwada et al. 2003, Tashima et al. 2006, Cui et al. 2008a, Cui et al. 2008b, Cui et al. 2010, Gessner et al. 2012, Ido et al. 2013, Cui et al. 2016). Some, ion-channel selectivity is supported by the finding that Wu40, one of the most potent BK-channel opener (Ohwada et al. 2003), only act as an average Shaker $\mathrm{K}_{\mathrm{v}}$ channel opener (Paper II). The binding site for Wu 40 on the BK channel has been suggested to be the intracellular S6-RCK1 (calcium-binding region)-linker (Gessner et al. 2012), not present in the Shaker $\mathrm{K}_{\mathrm{v}}$ channel. However, in a recent publication, uncertainty regarding the resinacid derivative binding site on the BK channel was emphasized (Cui et al. 2016). This ion-channel selectivity needs to be further investigated.

We envision that resin acids and their derivatives can become the first members of a new family of drugs against diseases caused by electrical hyperexcitability. 


\section{Acknowledgements}

I would like to express my gratitude to everyone who has helped me during these years, and in particular I would like to thank:

Professor Fredrik Elinder, my supervisor, thank you for your endless support! Thank you for always taking the time for short questions and long discussions, for your enthusiasm, and for giving me the opportunity to study these fascinating ion channels with the best possible supervisor! Your knowledge about ion channels (and everything else) is impressive.

Associate Professor David Engblom, my co-supervisor. Thank you for giving me the opportunity to do a project in your group at the beginning of time (or should I maybe thank the weird compounds from Actar?), and thank you for working in the same corridor as the ion channel people. It is reassuring to know that you are always close if I need you.

Sara Liin, my friend, colleague, and ion channel-mentor. Your support has been invaluable during these years. I cannot imagine how I should have done this without you by my side. You have answered hundreds of my questions, you taught me how to do surgery on a frog and you are an excellent travel companion (who even eats frogs with me).

Anna Nilsson, my beloved friend and former colleague. You have been an incredible support for me, both at work and outside. I admire your wisdom, your humor, and your ability to get things done. Since our first days in David's group (when Milen tried to teach us the important parts of transgene technology), we have had so much fun. Thank you for always being there!

Sofie Sundberg, my friend and office mate. Thank you for all coffee breaks and pep talks, whether if it is about never-ending kräksjuka or malfunctioning computers. Thank you for all the discussions (and for times when it only takes a glance), for all the laughs and for your ability to see things in a different perspective.

The present and past members of Group Elinder! Johan Brask, thank you for your scientific skills, your incredible ability to solve practical challenges (there is no noise that you can't fix). You are the big brother of group Elinder! Jakob

Renhorn, my office mate. Thank you for fruitful discussions, both scientific and about anything or nothing. Thank you for being you! Malin Silverå-Ejneby, for our fun and effective cooperation with the resin acids, for your enthusiasm, and your willingness to take the evening sessions at the setup. Your working capacity is 
impressive. Urban Karlsson, for your knowledge about neurons, for your stubbornness with struggling methods, and for your wisdom. Andreas Nolting, for your persistent work with the superchannel and your knowledge about pharma industry. Olle Rönnelid, for your ion-channel enthusiasm and kindness. Luca Conti and Sajjad Salari, for always being helpful and for scientific discussions. Ulrike Henrion, I am still fascinated by everything (and all mutants!) you did during your time in the lab. Per-Erik Lund, for the work you did, that will keep us busy for a while! Ulrika Englund, I miss you so in the lab!

To our collaborators who have made this thesis possible! The chemists at Valla, Xiongyu Wu, Katinka Ruda, Stefan Svensson, and Peter Konradsson, thank you for your great teamwork and patience with us when we ask for weird molecules and have stupid questions. In particular, thank you $\mathbf{W u}$, without you, we would never have synthesized (or purified!) many of the resin acid derivatives. Thank you for your contagious smile and your curiosity of ion channels. The simulation experts in Stockholm, Erik Lindahl and Sammy Yazdi, thank you for helping us with the molecular docking and molecular dynamics and also the nice pictures of the resin acid derivatives bound to the channel.

To the electrophysiology people! Björn Granseth, Sarah Lindström, Gonzalo Manuel Sanches, Erik Johansson, Johan Larsson, Anders Fridberger, Pierre Hakizimana, Batu Keceli, Iliya Elis, and Sonal Prasad for our nice and rewarding electro-journal clubs the last years. Thank you for reminding us to see the whole electrophysiological picture, for giving discussions and suggestions of experiments. Batu, also thank you for your ability to see the soft spots in all papers and Johan, thank you for invaluable help with the setup!

To other people at floor 11 during these years: Anders, Kiseko, Unn, Anna E, Johan, Linda, Ludmila, Ana-Maria, Takashi, Simin, Ayman, Daniel, Milen, Maarit, Anna K, Michael, Elahe, Joanna, Johanna, Andrea, and Alison for your scientific knowledge, for interesting discussions and many laughs in the coffeeroom.

To supportive staff: All staff at the animal facility for taking care of our frogs, giving them fredagsmys and protecting them from fires. Annette and Åsa at floor 9 for extraordinary fast and high quality sequencing. Håkan at KEF for friendly treatment and fast assistance. Anna and Camilla at the Cell Biology administration for all the help with paper forms, equipment, and frog invoices. Thank you for your contagious smiles!

To Larry Lundgren, for your kind words about our research and for proofreading this thesis. To Martin Pettersson at LiU-tryck for fast service and patience. 
To Noomi, Sofie, Marie, Malin, Elin, Lisa, Anna, Anna, Anna, Anna, Sarah, and Ronja and all other wonderful friends during master education, for making the anxiety-ridden, always too long examination periods (almost) to something fun. Thank you for all the röj at parties and kravaller, and thank you for helping me becoming an engineer.

To Jonsson and Lisa, for all support and fun discussions about everything and nothing. Thank you for all unannounced visits and for being excellent with Oskar and Tilde. To Jocke, for your kindness and trust, to Bobbo, Putte, Lönn, Kim, Malin, David and Aase for all fun midsummer- and New Year celebrations the last decade, for all memorable weekends in Bobbos stuga.

To Bea, my friend since childhood. Thank you for your support during these years, you are one of the persons that know me the best. Your intelligence and attention to people around you has always fascinated me. Jennie, my tvillingkusin, for all fun during the years, and for long discussions over some wine at night.

Till Johan, Lotta, Ludvig och Agnes. Tack för alla roliga utflykter, för er gästvänlighet de senaste somrarna. Tack Johan, för din klokhet och bra råd!

Till Gunnel och Roland, ni har varit ett enormt stöd för mig under dessa år. Tack för all omtanke och all hjälp som vi har fătt. Det är otrolig trygghet att veta att ni finns så nära och tveklöst ställer upp när vi behöver det. Jag är så tacksam och bättre svärföräldrar finns inte!

Till Emma, Mattias, Walter och Holger. Tack för er hjälp och kärlek! Emma, min vän och storasyster, du är så cool och jag ser upp till dig så mycket! Du har alltid stöttat mig och funnits där för mig. Tack för ditt otroliga stöd under riktigt tuffa perioder, för alla tusentals skratt och för att du alltid finns där.

Mamma och pappa. Det finns inte ord för att uttrycka den tacksamhet som jag känner gentemot er. Tack för all hjälp, tack för att ni alltid har trott på mig och för att ni har stöttat mina val i livet. Tack för den trygga och kärleksfulla uppväxt som jag och Emma fick, att ni lärde oss ta ansvar och gjorde oss till dem vi är. Tack för er ovillkorliga kärlek.

Erik, Oskar och Tilde. Det är tack vare er tre som jag har klarat av det här, tack för att ni varje dag påminner mig om vad som är det viktigaste i livet. Erik, tack för att du alltid står vid min sida, för din intelligens och för att du orkar lyssna på mig när jag maler på om jonkanaler. Jag älskar er så! 


\section{References}

Armstrong, C. M. (1981). "Sodium channels and gating currents." Physiol Rev 61(3): 644-683.

Armstrong, C. M. and Bezanilla, F. (1973). "Currents related to movement of the gating particles of the sodium channels." Nature 242(5398): 459-461.

Armstrong, C. M. and Bezanilla, F. (1974). "Charge movement associated with the opening and closing of the activation gates of the Na channels." $J$ Gen Physiol 63(5): 533-552.

Armstrong, C. M. and Bezanilla, F. (1977). "Inactivation of the sodium channel. II. Gating current experiments." J Gen Physiol 70(5): 567-590.

Armstrong, C. M. and Binstock, L. (1965). "Anomalous Rectification in the Squid Giant Axon Injected with Tetraethylammonium Chloride." J Gen Physiol 48: 859-872.

Ashcroft, F. M. (2000). Ion channels and disease (1st ed.). San Diego, CA: Academic press.

Barrese, V., Miceli, F., Soldovieri, M. V., Ambrosino, P., Iannotti, F. A., Cilio, M. R. and Taglialatela, M. (2010). "Neuronal potassium channel openers in the management of epilepsy: role and potential of retigabine." Clin Pharmacol 2: $225-236$.

Beath, O. A. (1912). On Abietic Acid and Related Resin Acids from Oleoresin of American Conifers, University of Wisconsin, Madison.

Bernstein, J. (1902). "Untersuchungen zur Thermodynamik der bioelektrischen Ströme." Archiv für die gesamte Physiologie des Menschen und der Tiere 92(10-12): 521-562.

Billman, G. E., Hallaq, H. and Leaf, A. (1994). "Prevention of ischemia-induced ventricular fibrillation by omega 3 fatty acids." Proc Natl Acad Sci U S A 91(10): 4427-4430.

Blunck, R. and Batulan, Z. (2012). "Mechanism of electromechanical coupling in voltage-gated potassium channels." Front Pharmacol 3: 166.

Boland, L. M. and Drzewiecki, M. M. (2008). "Polyunsaturated fatty acid modulation of voltage-gated ion channels." Cell Biochem Biophys 52(2): 59-84.

Brickel, N., Gandhi, P., VanLandingham, K., Hammond, J. and DeRossett, S. (2012). "The urinary safety profile and secondary renal effects of retigabine (ezogabine): a first-in-class antiepileptic drug that targets KCNQ (K(v)7) potassium channels." Epilepsia 53(4): 606-612.

Brodie, M. J., Barry, S. J., Bamagous, G. A., Norrie, J. D. and Kwan, P. (2012). "Patterns of treatment response in newly diagnosed epilepsy." Neurology 78(20): 1548-1554.

Börjesson, S. I. and Elinder, F. (2008). "Structure, function, and modification of the voltage sensor in voltage-gated ion channels." Cell Biochem Biophys 52(3): 149-174.

Börjesson, S. I. and Elinder, F. (2011). "An electrostatic potassium channel opener targeting the final voltage sensor transition." J Gen Physiol 137(6): 563577.

Börjesson, S. I., Hammarström, S. and Elinder, F. (2008). "Lipoelectric modification of ion channel voltage gating by polyunsaturated fatty acids." Biophys $J$ 95(5): 2242-2253. 
Börjesson, S. I., Parkkari, T., Hammarström, S. and Elinder, F. (2010). "Electrostatic tuning of cellular excitability." Biophys $J$ 98(3): 396-403.

Catterall, W. A. (1980). "Neurotoxins that act on voltage-sensitive sodium channels in excitable membranes." Annu Rev Pharmacol Toxicol 20: 15-43.

Catterall, W. A. (1986). "Voltage-Dependent Gating of Sodium-Channels Correlating Structure and Function." Trends in Neurosciences 9(1): 7-10.

Catterall, W. A., Cestele, S., Yarov-Yarovoy, V., Yu, F. H., Konoki, K. and Scheuer, T. (2007). "Voltage-gated ion channels and gating modifier toxins." Toxicon 49(2): 124-141.

Cavallo, G., Metrangolo, P., Milani, R., Pilati, T., Priimagi, A., Resnati, G. and Terraneo, G. (2016). "The Halogen Bond." Chem Rev 116(4): 2478-2601.

Clark, S., Antell, A. and Kaufman, K. (2015). "New antiepileptic medication linked to blue discoloration of the skin and eyes." Ther Adv Drug Saf 6(1): 15-19.

Clugston, M. and Flemming, R. (2000). Advanced chemistry, Oxford University Press.

Conti, L., Renhorn, J., Gabrielsson, A., Turesson, F., Liin, S. I., Lindahl, E. and Elinder, F. (2016). "Reciprocal voltage sensor-to-pore coupling leads to potassium channel C-type inactivation." Sci Rep 6: 27562.

Cui, Y. M., Liu, X. L., Zhang, W. M., Lin, H. X., Ohwada, T., Ido, K. and Sawada, K. (2016). "The synthesis and BK channel-opening activity of $\mathrm{N}$ acylaminoalkyloxime derivatives of dehydroabietic acid." Bioorg Med Chem Lett 26(2): 283-287.

Cui, Y. M., Yasutomi, E., Otani, Y., Ido, K., Yoshinaga, T., Sawada, K. and Ohwada, T. (2010). "Design, synthesis, and characterization of BK channel openers based on oximation of abietane diterpene derivatives." Bioorg Med Chem 18(24): 8642-8659.

Cui, Y. M., Yasutomi, E., Otani, Y., Yoshinaga, T., Ido, K., Sawada, K., Kawahata, M., Yamaguchi, K. and Ohwada, T. (2008a). "Novel oxime and oxime ether derivatives of 12,14-dichlorodehydroabietic acid: design, synthesis, and BK channel-opening activity." Bioorg Med Chem Lett 18(24): 6386-6389.

Cui, Y. M., Yasutomi, E., Otani, Y., Yoshinaga, T., Ido, K., Sawada, K. and Ohwada, T. (2008b). "Design, synthesis and characterization of podocarpate derivatives as openers of BK channels." Bioorg Med Chem Lett 18(19): 5197-5200.

DeCaen, P. G., Yarov-Yarovoy, V., Sharp, E. M., Scheuer, T. and Catterall, W. A. (2009). "Sequential formation of ion pairs during activation of a sodium channel voltage sensor." Proc Natl Acad Sci U S A 106(52): 22498-22503.

DeCaen, P. G., Yarov-Yarovoy, V., Zhao, Y., Scheuer, T. and Catterall, W. A. (2008).

"Disulfide locking a sodium channel voltage sensor reveals ion pair formation during activation." Proc Natl Acad Sci U S A 105(39): 1514215147 .

Delemotte, L., Tarek, M., Klein, M. L., Amaral, C. and Treptow, W. (2011).

"Intermediate states of the Kv1.2 voltage sensor from atomistic molecular dynamics simulations." Proc Natl Acad Sci U S A 108(15): 6109-6114.

Du Bois-Reymond, E. (1849). Untersuchungen uber thierische Elektricitat.

Elinder, F. and Arhem, P. (2003). "Metal ion effects on ion channel gating." $Q$ Rev Biophys 36(4): 373-427.

Elinder, F. and Liin, S. I. (2017). "Actions and Mechanisms of Polyunsaturated Fatty Acids on Voltage-Gated Ion Channels." Front Physiol 8: 43. 
Frank, H. Y., Yarov-Yarovoy, V., Gutman, G. A. and Catterall, W. A. (2005).

"Overview of molecular relationships in the voltage-gated ion channel superfamily." Pharmacological reviews 57(4): 387-395.

Fraser, D. D., Whiting, S., Andrew, R. D., Macdonald, E. A., Musa-Veloso, K. and Cunnane, S. C. (2003). "Elevated polyunsaturated fatty acids in blood serum obtained from children on the ketogenic diet." Neurology 6o(6): 1026-1029.

Galvani, L. (1791). Bon. Sci. Art. Inst. Acad. Comm. 7: 363-418.

Garin Shkolnik, T., Feuerman, H., Didkovsky, E., Kaplan, I., Bergman, R., Pavlovsky, L. and Hodak, E. (2014). "Blue-gray mucocutaneous discoloration: a new adverse effect of ezogabine." JAMA Dermatol 150(9): 984-989.

Gessner, G., Cui, Y. M., Otani, Y., Ohwada, T., Soom, M., Hoshi, T. and Heinemann, S. H. (2012). "Molecular mechanism of pharmacological activation of BK channels." Proc Natl Acad Sci US A 109(9): 3552-3557.

GlaxoSmithKline (2016). ADVANCE NOTIFICATION OF TROBALT® DISCONTINUATION. Press release, Retrieved from https://assets.publishing.service.gov.uk/media/57fe4b6640fob671380oo ooc/Trobalt_letter.pdf

Gonzalez, M. A. (2015). "Aromatic abietane diterpenoids: their biological activity and synthesis." Natural Product Reports 32(5): 684-704.

Grabe, M., Lai, H. C., Jain, M., Jan, Y. N. and Jan, L. Y. (2007). "Structure prediction for the down state of a potassium channel voltage sensor." Nature 445(7127): 550-553.

Guy, H. R. and Seetharamulu, P. (1986). "Molecular model of the action potential sodium channel." Proc Natl Acad Sci U S A 83(2): 508-512.

Harrison, D. C., Sprouse, J. H. and Morrow, A. G. (1963). "The Antiarrhythmic Properties of Lidocaine and Procaine Amide. Clinical and Physiologic Studies of Their Cardiovascular Effects in Man." Circulation 28: 486-491.

Henrion, U., Renhorn, J., Börjesson, S. I., Nelson, E. M., Schwaiger, C. S., Bjelkmar, P., Wallner, B., Lindahl, E. and Elinder, F. (2012). "Tracking a complete voltage-sensor cycle with metal-ion bridges." Proc Natl Acad Sci US A 109(22): 8552-8557.

Hille, B. (1972). "The permeability of the sodium channel to metal cations in myelinated nerve." J Gen Physiol 59(6): 637-658.

Hille, B. (1977a). "Local anaesthetics: Hydrophilic and hydrophobic pathways for the drug-receptor reaction." J Gen Physiol 69: 497-575.

Hille, B. (1977b). "The pH-dependent rate of action of local anesthetics on the node of Ranvier." J Gen Physiol 69(4): 475-496.

Hille, B. (2001). Ion channels of excitable membranes, Sinauer Sunderland, MA.

Hille, B., Woodhull, A. M. and Shapiro, B. I. (1975). "Negative surface charge near sodium channels of nerve: divalent ions, monovalent ions, and pH." Philos Trans $R$ Soc Lond B Biol Sci 270(908): 301-318.

Hock, C. E., Beck, L. D., Bodine, R. C. and Reibel, D. K. (1990). "Influence of dietary n-3 fatty acids on myocardial ischemia and reperfusion." Am J Physiol 259(5 Pt 2): H1518-1526.

Hodgkin, A. L. and Huxley, A. F. (1952a). "The components of membrane conductance in the giant axon of Loligo." $J$ Physiol 116(4): 473-496.

Hodgkin, A. L. and Huxley, A. F. (1952b). "Currents carried by sodium and potassium ions through the membrane of the giant axon of Loligo." $J$ Physiol 116(4): 449. 
Hodgkin, A. L. and Huxley, A. F. (1952c). "The dual effect of membrane potential on sodium conductance in the giant axon of Loligo." $J$ Physiol 116(4): 497506.

Hodgkin, A. L. and Huxley, A. F. (1952d). "A quantitative description of membrane current and its application to conduction and excitation in nerve." $J$ Physiol 117(4): 500-544.

Hodgkin, A. L., Huxley, A. F. and Katz, B. (1952). "Measurement of current-voltage relations in the membrane of the giant axon of Loligo." J Physiol 116(4): 424-448.

Hodgkin, A. L. and Katz, B. (1949). "The effect of sodium ions on the electrical activity of giant axon of the squid." $J$ Physiol 108(1): 37-77.

Hondeghem, L. M. and Katzung, B. G. (1977). "Time- and voltage-dependent interactions of antiarrhythmic drugs with cardiac sodium channels." Biochim Biophys Acta 472(3-4): 373-398.

Hoshi, T., Zagotta, W. N. and Aldrich, R. W. (1990). "Biophysical and molecular mechanisms of Shaker potassium channel inactivation." Science 250(4980): 533-538.

Hoshi, T., Zagotta, W. N. and Aldrich, R. W. (1991). "Two types of inactivation in Shaker K+ channels: effects of alterations in the carboxy-terminal region." Neuron 7(4): 547-556.

Hu, H. N., Zhou, P. Z., Chen, F., Li, M., Nan, F. J. and Gao, Z. B. (2013). "Discovery of a retigabine derivative that inhibits KCNQ2 potassium channels." Acta Pharmacol Sin 34(10): 1359-1366.

Ido, K., Ohwada, T., Yasutomi, E., Yoshinaga, T., Arai, T., Kato, M. and Sawada, K. (2013). "Screening quality for Ca2+-activated potassium channel in IonWorks Quattro is greatly improved by using BAPTA-AM and ionomycin." J Pharmacol Toxicol Methods 67(1): 16-24.

Imaizumi, Y. (2002). "Molecular Basis of Pimarane Compounds as Novel Activators of Large-Conductance Ca2+-Activated K+ Channel alpha -Subunit." Molecular Pharmacology 62(4): 836-846.

Jan, L. Y. and Jan, Y. N. (1990). "A superfamily of ion channels." Nature 345(6277): 672.

Jentsch, T. J. (2000). "Neuronal KCNQ potassium channels: physiology and role in disease." Nat Rev Neurosci 1(1): 21-30.

Jiang, Y., Lee, A., Chen, J., Ruta, V., Cadene, M., Chait, B. T. and MacKinnon, R. (2003a). "X-ray structure of a voltage-dependent K+ channel." Nature 423(6935): 33-41.

Jiang, Y., Ruta, V., Chen, J., Lee, A. and MacKinnon, R. (2003b). "The principle of gating charge movement in a voltage-dependent $\mathrm{K}+$ channel." Nature 423(6935): 42-48.

Kamb, A., Iverson, L. E. and Tanouye, M. A. (1987). "Molecular characterization of Shaker, a Drosophila gene that encodes a potassium channel." Cell 50(3): 405-413.

Keynes, R. D. and Elinder, F. (1998). "Modelling the activation, opening, inactivation and reopening of the voltage-gated sodium channel." Proc Biol Sci 265(1393): 263-270.

Keynes, R. D. and Elinder, F. (1999). "The screw-helical voltage gating of ion channels." Proc Biol Sci 266(1421): 843-852.

Keynes, R. D. and Rojas, E. (1974). "Kinetics and steady-state properties of the charged system controlling sodium conductance in the squid giant axon." J Physiol 239(2): 393-434. 
Kobayashi, K., Ito, M., Miyajima, T., Fujii, T. and Okuno, T. (1999). "Successful management of intractable epilepsy with intravenous lidocain and lidocain tapes." Pediatr Neurol 21(1): 476-480.

Kurata, H. T. and Fedida, D. (2006). "A structural interpretation of voltage-gated potassium channel inactivation." Prog Biophys Mol Biol 92(2): 185-208.

Labro, A. J., Lacroix, J. J., Villalba-Galea, C. A., Snyders, D. J. and Bezanilla, F. (2012). "Molecular mechanism for depolarization-induced modulation of Kv channel closure." J Gen Physiol 140(5): 481-493.

Lacroix, J. J., Labro, A. J. and Bezanilla, F. (2011). "Properties of deactivation gating currents in Shaker channels." Biophys $J$ 100(5): L28-30.

Larsson, H. P. and Elinder, F. (2000). "A conserved glutamate is important for slow inactivation in K+ channels." Neuron 27(3): 573-583.

Lecar, H., Larsson, H. P. and Grabe, M. (2003). "Electrostatic model of S4 motion in voltage-gated ion channels." Biophys $J$ 85(5): 2854-2864.

Lefevre, F. and Aronson, N. (2000). "Ketogenic diet for the treatment of refractory epilepsy in children: A systematic review of efficacy." Pediatrics 105(4): E46.

Liin, S. I., Karlsson, U., Bentzen, B. H., Schmitt, N. and Elinder, F. (2016). "Polyunsaturated fatty acids are potent openers of human M-channels expressed in Xenopus laevis oocytes." Acta Physiol (Oxf) 218(1): 28-37.

Liin, S. I., Silverå Ejneby, M., Barro-Soria, R., Skarsfeldt, M. A., Larsson, J. E., Starck Härlin, F., Parkkari, T., Bentzen, B. H., Schmitt, N., Larsson, H. P. and Elinder, F. (2015). "Polyunsaturated fatty acid analogs act antiarrhythmically on the cardiac IKs channel." Proc Natl Acad Sci U S A 112(18): 5714-5719.

Long, S. B., Campbell, E. B. and Mackinnon, R. (2005a). "Crystal structure of a mammalian voltage-dependent Shaker family K+ channel." Science 309(5736): 897-903.

Long, S. B., Campbell, E. B. and Mackinnon, R. (2005b). "Voltage sensor of Kv1.2: structural basis of electromechanical coupling." Science 309(5736): 903908.

Long, S. B., Tao, X., Campbell, E. B. and MacKinnon, R. (2007). "Atomic structure of a voltage-dependent $\mathrm{K}+$ channel in a lipid membrane-like environment." Nature 450(7168): 376-382.

Loring, D. W., Marino, S. and Meador, K. J. (2007). "Neuropsychological and behavioral effects of antiepilepsy drugs." Neuropsychol Rev 17(4): 413425 .

Loscher, W., Klitgaard, H., Twyman, R. E. and Schmidt, D. (2013). "New avenues for anti-epileptic drug discovery and development." Nat Rev Drug Discov 12(10): 757-776.

Löfgren, N. (1948). Studies on local anesthetics: Xylocaine: a new synthetic drug, Hæggströms boktr.

MacKinnon, R. (1991). "Determination of the subunit stoichiometry of a voltageactivated potassium channel." Nature 350(6315): 232-235.

Main, M. J., Cryan, J. E., Dupere, J. R., Cox, B., Clare, J. J. and Burbidge, S. A. (2000). "Modulation of KCNQ2/3 potassium channels by the novel anticonvulsant retigabine." Mol Pharmacol 58(2): 253-262.

McLennan, P. L., Abeywardena, M. Y. and Charnock, J. S. (1985). "Influence of dietary lipids on arrhythmias and infarction after coronary artery ligation in rats." Can $J$ Physiol Pharmacol 63(11): 1411-1417. 
Milescu, M., Lee, H. C., Bae, C. H., Kim, J. I. and Swartz, K. J. (2013). "Opening the shaker K+ channel with hanatoxin." J Gen Physiol 141(2): 203-216.

Miller, C., Moczydlowski, E., Latorre, R. and Phillips, M. (1985). "Charybdotoxin, a protein inhibitor of single Ca2+-activated $\mathrm{K}+$ channels from mammalian skeletal muscle." Nature 313(6000): 316-318.

Mori, K., Ito, H., Toda, Y., Hashimoto, T., Miyazaki, M., Saijo, T. and Kuroda, Y. (2004). "Successful management of intractable epilepsy with lidocaine tapes and continuous subcutaneous lidocaine infusion." Epilepsia 45(10): 1287-1290.

Narahashi, T., Moore, J. W. and Scott, W. R. (1964). "Tetrodotoxin Blockage of Sodium Conductance Increase in Lobster Giant Axons." J Gen Physiol 47: 965-974.

Noda, M., Ikeda, T., Suzuki, H., Takeshima, H., Takahashi, T., Kuno, M. and Numa, S. (1986). "Expression of functional sodium channels from cloned cDNA." Nature 322(6082): 826-828.

Noda, M., Shimizu, S., Tanabe, T., Takai, T., Kayano, T., Ikeda, T., Takahashi, H., Nakayama, H., Kanaoka, Y., Minamino, N. and et al. (1984). "Primary structure of Electrophorus electricus sodium channel deduced from cDNA sequence." Nature 312(5990): 121-127.

Norin, T. and Winell, B. (1971). "Diterpenoids of cones from two Cedrus species." Phytochemistry 10(11): 2818-2821.

Ohwada, T., Nonomura, T., Maki, K., Sakamoto, K., Ohya, S., Muraki, K. and Imaizumi, Y. (2003). "Dehydroabietic acid derivatives as a novel scaffold for large-conductance calcium-activated $\mathrm{K}+$ channel openers." Bioorg Med Chem Lett 13(22): 3971-3974.

Olcese, R., Latorre, R., Toro, L., Bezanilla, F. and Stefani, E. (1997). "Correlation between charge movement and ionic current during slow inactivation in Shaker K+ channels." J Gen Physiol 110(5): 579-589.

Ottosson, N. E., Liin, S. I. and Elinder, F. (2014). "Drug-induced ion channel opening tuned by the voltage sensor charge profile." J Gen Physiol 143(2): 173-182.

Ottosson, N. E., Wu, X., Nolting, A., Karlsson, U., Lund, P. E., Ruda, K., Svensson, S., Konradsson, P. and Elinder, F. (2015). "Resin-acid derivatives as potent electrostatic openers of voltage-gated K channels and suppressors of neuronal excitability." Sci Rep 5: 13278.

Overington, J. P., Al-Lazikani, B. and Hopkins, A. L. (2006). "How many drug targets are there?" Nat Rev Drug Discov 5(12): 993-996.

Papazian, D. M., Schwarz, T. L., Tempel, B. L., Jan, Y. N. and Jan, L. Y. (1987). "Cloning of genomic and complementary DNA from Shaker, a putative potassium channel gene from Drosophila." Science 237(4816): 749-753.

Papazian, D. M., Shao, X. M., Seoh, S. A., Mock, A. F., Huang, Y. and Wainstock, D. H. (1995). "Electrostatic interactions of S4 voltage sensor in Shaker K+ channel." Neuron 14(6): 1293-1301.

Pathak, M., Kurtz, L., Tombola, F. and Isacoff, E. (2005). "The cooperative voltage sensor motion that gates a potassium channel." J Gen Physiol 125(1): 5769.

Peretz, A., Pell, L., Gofman, Y., Haitin, Y., Shamgar, L., Patrich, E., Kornilov, P., Gourgy-Hacohen, O., Ben-Tal, N. and Attali, B. (2010). "Targeting the voltage sensor of Kv7.2 voltage-gated $\mathrm{K}+$ channels with a new gatingmodifier." Proc Natl Acad Sci U S A 107(35): 15637-15642.

Pongs, O., Kecskemethy, N., Muller, R., Krah-Jentgens, I., Baumann, A., Kiltz, H. H., Canal, I., Llamazares, S. and Ferrus, A. (1988). "Shaker encodes a family 
of putative potassium channel proteins in the nervous system of Drosophila." EMBO J 7(4): 1087-1096.

Ragsdale, D. S., McPhee, J. C., Scheuer, T. and Catterall, W. A. (1996). "Common molecular determinants of local anesthetic, antiarrhythmic, and anticonvulsant block of voltage-gated $\mathrm{Na}+$ channels." Proc Natl Acad Sci $U S A$ 93(17): 9270-9275.

Ringer, S. (1882). "Concerning the influence exerted by each of the constituents of the blood on the contraction of the ventricle." J Physiol 3(5-6): 380 .

Ringer, S. (1883). "A further Contribution regarding the influence of the different Constituents of the Blood on the Contraction of the Heart." J Physiol 4(1): 29-42.23.

Rogawski, M. A. and Loscher, W. (2004). "The neurobiology of antiepileptic drugs." Nat Rev Neurosci 5(7): 553-564.

Rogers, J. C., Qu, Y., Tanada, T. N., Scheuer, T. and Catterall, W. A. (1996). "Molecular determinants of high affinity binding of alpha-scorpion toxin and sea anemone toxin in the $\mathrm{S}_{3}-\mathrm{S} 4$ extracellular loop in domain IV of the $\mathrm{Na}+$ channel alpha subunit." J Biol Chem 271(27): 15950-15962.

Rundfeldt, C. (1997). "The new anticonvulsant retigabine (D-23129) acts as an opener of K+ channels in neuronal cells." Eur J Pharmacol 336(2-3): 243249.

San Feliciano, A., Gordaliza, M., Salinero, M. A. and Miguel del Corral, J. M. (1993). "Abietane acids: sources, biological activities, and therapeutic uses." Planta Med 59(6): 485-490.

Sankar, R. and Holmes, G. L. (2004). "Mechanisms of action for the commonly used antiepileptic drugs: relevance to antiepileptic drug-associated neurobehavioral adverse effects." J Child Neurol 19 Suppl 1: S6-14.

Schuele, S. U. and Luders, H. O. (2008). "Intractable epilepsy: management and therapeutic alternatives." Lancet Neurol 7(6): 514-524.

Sillanpaa, M. and Schmidt, D. (2006). "Natural history of treated childhood-onset epilepsy: prospective, long-term population-based study." Brain 129(Pt 3): 617-624.

Smith-Maxwell, C. J., Ledwell, J. L. and Aldrich, R. W. (1998). "Uncharged S4 residues and cooperativity in voltage-dependent potassium channel activation." J Gen Physiol 111(3): 421-439.

Southworth, J. L. (1950). "Ventricular Fibrillation Precipitated by Cardiac Catheterization." JAMA 143(8): 717-720.

Spector, A. A. (2001). "Plasma free fatty acid and lipoproteins as sources of polyunsaturated fatty acid for the brain." J Mol Neurosci 16(2-3): 159-165.

Starkus, J. G., Kuschel, L., Rayner, M. D. and Heinemann, S. H. (1997). "Ion conduction through C-type inactivated Shaker channels." J Gen Physiol 110(5): 539-550.

Suh, B. C. and Hille, B. (2008). "PIP2 is a necessary cofactor for ion channel function: how and why?" Annu Rev Biophys 37(1): 175-195.

Swartz, K. J. (2007). "Tarantula toxins interacting with voltage sensors in potassium channels." Toxicon 49(2): 213-230.

Swartz, K. J. and MacKinnon, R. (1995). "An inhibitor of the Kv2.1 potassium channel isolated from the venom of a Chilean tarantula." Neuron 15(4): 941-949.

Swartz, K. J. and MacKinnon, R. (1997). "Mapping the receptor site for hanatoxin, a gating modifier of voltage-dependent K+ channels." Neuron 18(4): 675682. 
Taha, A. Y., Ryan, M. A. and Cunnane, S. C. (2005). "Despite transient ketosis, the classic high-fat ketogenic diet induces marked changes in fatty acid metabolism in rats." Metabolism 54(9): 1127-1132.

Tanabe, T., Takeshima, H., Mikami, A., Flockerzi, V., Takahashi, H., Kangawa, K., Kojima, M., Matsuo, H., Hirose, T. and Numa, S. (1987). "Primary structure of the receptor for calcium channel blockers from skeletal muscle." Nature 328(6128): 313-318.

Tasaki, I. and Hagiwar, A. S. (1957). "Demonstration of two stable potential states in the squid giant axon under tetraethylammonium chloride." J Gen Physiol 40(6): 859-885.

Tashima, T., Toriumi, Y., Mochizuki, Y., Nonomura, T., Nagaoka, S., Furukawa, K., Tsuru, H., Adachi-Akahane, S. and Ohwada, T. (2006). "Design, synthesis, and BK channel-opening activity of hexahydrodibenzazepinone derivatives." Bioorg Med Chem 14(23): 8014-8031.

Tempel, B. L., Papazian, D. M., Schwarz, T. L., Jan, Y. N. and Jan, L. Y. (1987). "Sequence of a Probable Potassium Channel Component Encoded at Shaker Locus of Drosophila." Science 237(4816): 770-775.

Tigerholm, J., Börjesson, S. I., Lundberg, L., Elinder, F. and Fransén, E. (2012). "Dampening of hyperexcitability in CA1 pyramidal neurons by polyunsaturated fatty acids acting on voltage-gated ion channels." PLoS One 7(9): e44388.

Tombola, F., Pathak, M. M., Gorostiza, P. and Isacoff, E. Y. (2007). "The twisted ionpermeation pathway of a resting voltage-sensing domain." Nature 445(7127): 546-549.

Wang, A. W., Yang, R. and Kurata, H. T. (2017). "Sequence determinants of subtypespecific actions of KCNQ channel openers." J Physiol 595(3): 663-676.

Vargas, E., Yarov-Yarovoy, V., Khalili-Araghi, F., Catterall, W. A., Klein, M. L., Tarek, M., Lindahl, E., Schulten, K., Perozo, E., Bezanilla, F. and Roux, B. (2012). "An emerging consensus on voltage-dependent gating from computational modeling and molecular dynamics simulations." J Gen Physiol 140(6): 587-594.

Webster, S. M., Del Camino, D., Dekker, J. P. and Yellen, G. (2004). "Intracellular gate opening in Shaker K+ channels defined by high-affinity metal bridges." Nature 428(6985): 864-868.

Wickenden, A. D., Krajewski, J. L., London, B., Wagoner, P. K., Wilson, W. A., Clark, S., Roeloffs, R., McNaughton-Smith, G. and Rigdon, G. C. (2008). "N-(6chloro-pyridin-3-yl)-3,4-difluoro-benzamide (ICA-27243): a novel, selective KCNQ2/Q3 potassium channel activator." Mol Pharmacol 73(3): 977-986.

Wilder, R. M. (1921). "The effect of ketonemia on course of epilepsy." Mayo Clin Bull 2: 307-308.

Villalba-Galea, C. A. (2016). "Hysteresis in voltage-gated channels." Channels (Austin): 1-16.

Vreugdenhil, M., Bruehl, C., Voskuyl, R. A., Kang, J. X., Leaf, A. and Wadman, W. J. (1996). "Polyunsaturated fatty acids modulate sodium and calcium currents in CA1 neurons." Proc Natl Acad Sci U S A 93(22): 12559-12563.

Wuttke, T. V., Seebohm, G., Bail, S., Maljevic, S. and Lerche, H. (2005). "The new anticonvulsant retigabine favors voltage-dependent opening of the Kv7.2 (KCNQ2) channel by binding to its activation gate." Mol Pharmacol 67(4): 1009-1017. 
Xiao, Y. and Li, X. (1999). "Polyunsaturated fatty acids modify mouse hippocampal neuronal excitability during excitotoxic or convulsant stimulation." Brain Res 846(1): 112-121.

Xiao, Y., Tang, J., Hu, W., Xie, J., Maertens, C., Tytgat, J. and Liang, S. (2005). "Jingzhaotoxin-I, a novel spider neurotoxin preferentially inhibiting cardiac sodium channel inactivation." $J$ Biol Chem 280(13): 12069-12076.

Xu, X. P., Erichsen, D., Börjesson, S. I., Dahlin, M., Amark, P. and Elinder, F. (2008). "Polyunsaturated fatty acids and cerebrospinal fluid from children on the ketogenic diet open a voltage-gated $\mathrm{K}$ channel: a putative mechanism of antiseizure action." Epilepsy Res 80(1): 57-66.

Yazdi, S., Stein, M., Elinder, F., Andersson, M. and Lindahl, E. (2016). "The Molecular Basis of Polyunsaturated Fatty Acid Interactions with the Shaker Voltage-Gated Potassium Channel." PLoS Comput Biol 12(1): e1004704.

Yu, F. H., Yarov-Yarovoy, V., Gutman, G. A. and Catterall, W. A. (2005). "Overview of molecular relationships in the voltage-gated ion channel superfamily." Pharmacol Rev 57(4): 387-395.

Yue, C. and Yaari, Y. (2004). "KCNQ/M channels control spike afterdepolarization and burst generation in hippocampal neurons." J Neurosci 24(19): 46144624.

Yue, J. F., Qiao, G. H., Liu, N., Nan, F. J. and Gao, Z. B. (2016). "Novel KCNQ2 channel activators discovered using fluorescence-based and automated patch-clamp-based high-throughput screening techniques." Acta Pharmacol Sin 37(1): 105-110.

Zagotta, W. N., Hoshi, T. and Aldrich, R. W. (1994). "Shaker potassium channel gating. III: Evaluation of kinetic models for activation." J Gen Physiol 103(2): 321-362.

Zeiler, F. A., Zeiler, K. J., Kazina, C. J., Teitelbaum, J., Gillman, L. M. and West, M. (2015). "Lidocaine for status epilepticus in adults." Seizure 31: 41-48. 



\section{Papers}

The articles associated with this thesis have been removed for copyright reasons. For more details about these see:

http://urn.kb.se/resolve?urn=urn:nbn:se:liu:diva-136686 